\title{
Archaeological Monitoring for the City of San Antonio: Henry B. Gonzalez Convention Center Expansion
}

Cynthia L. Tennis

Center for Archaeological Research

I. Waynne Cox

Center for Archaeological Research

Follow this and additional works at: https://scholarworks.sfasu.edu/ita

Part of the American Material Culture Commons, Archaeological Anthropology Commons, Environmental Studies Commons, Other American Studies Commons, Other Arts and Humanities Commons, Other History of Art, Architecture, and Archaeology Commons, and the United States History Commons

Tell us how this article helped you.

This Article is brought to you for free and open access by the Center for Regional Heritage Research at SFA ScholarWorks. It has been accepted for inclusion in Index of Texas Archaeology: Open Access Gray Literature from the Lone Star State by an authorized editor of SFA ScholarWorks. For more information, please contact cdsscholarworks@sfasu.edu. 


\section{Archaeological Monitoring for the City of San Antonio: Henry B. Gonzalez Convention Center Expansion}

\section{Creative Commons License}

\section{(c) (1) \&}

This work is licensed under a Creative Commons Attribution-NonCommercial 4.0 International License 


\section{Archaeological Monitoring for the City of San Antonio: Henry B. Gonzalez Convention Center Expansion}

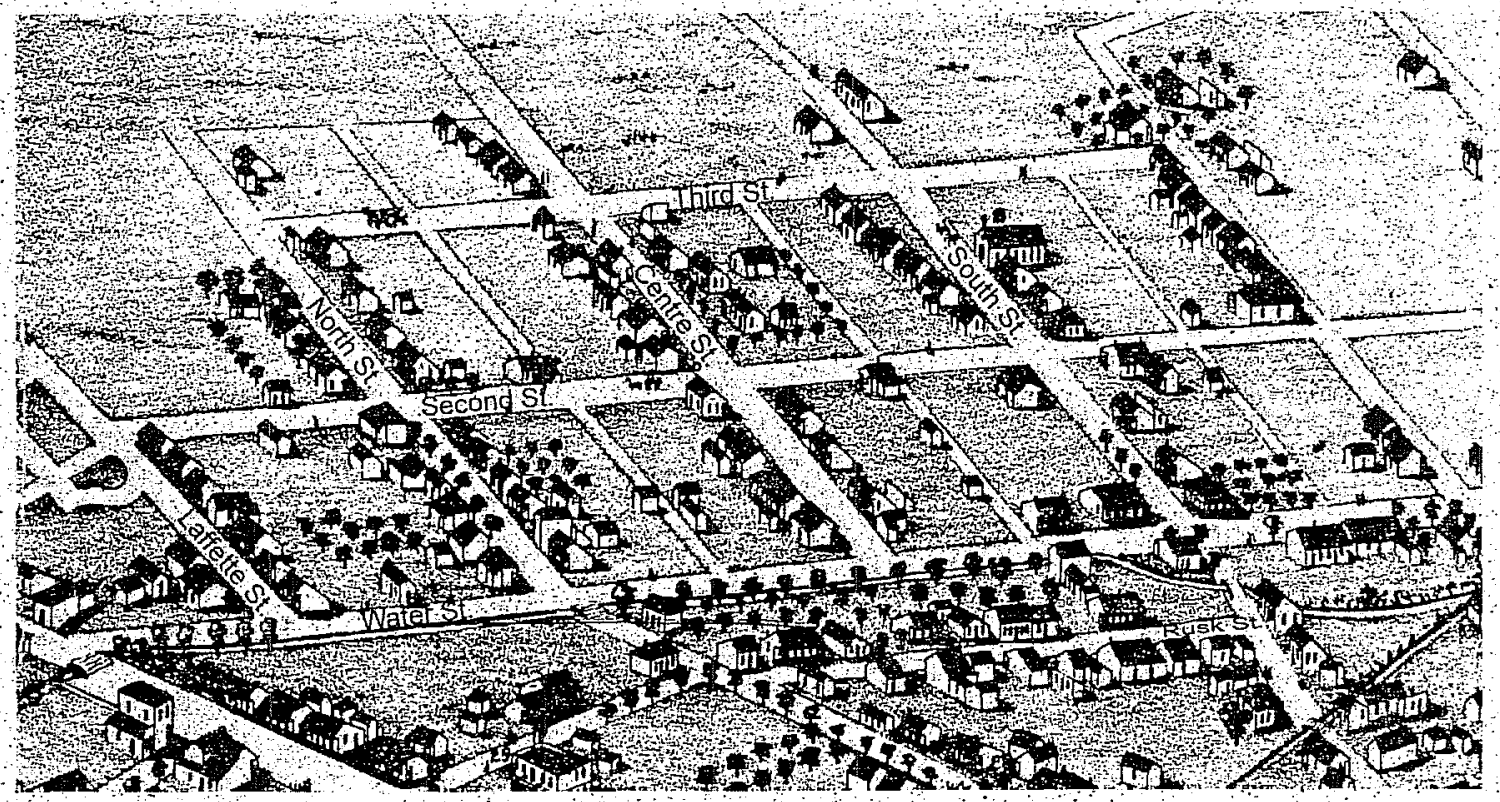

\section{Cynthia L. Tennis and I. Waynne Cox}

Center for Archaeological Research The University of Texas at San Antonio Archaeological Survey Report, No. 284 1998

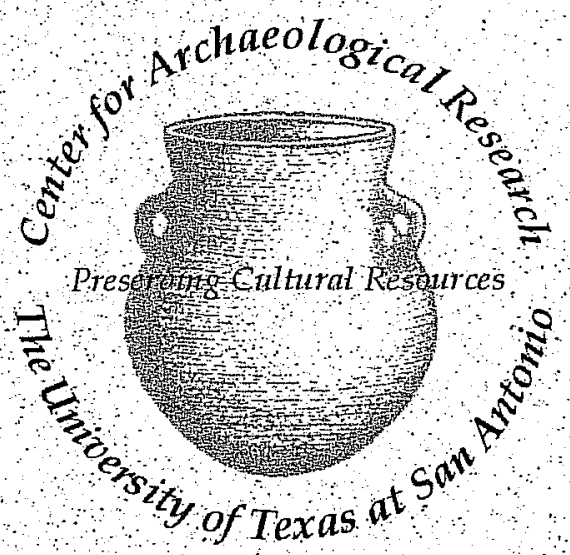





\title{
Archaeological Monitoring for the City of San Antonio: \\ Henry B. Gonzalez Convention Center Expansion
}

\section{Cynthia L. Tennis and I. Waynne Cox}

\author{
Robert J. Hard and C. Britt Bousman \\ Principal Investigators
}

Texas Antiquities Permit No. 1776

\author{
(C)1998
}

Center for Archaeological Research

The University of Texas at San Antonio

Archaeological Survey Report, No. 284 
The following information is provided in accordance with the General Rules of Practice and Procedure, Chapter 41.11 (Investigative Reports), Texas Antiquities Committee:

1. Type of investigation: Monitoring and testing

2. Project name: City of San Antonio: Henry B. Gonzalez Convention Center Expansion

3. County: Bexar

4. Principal investigators: Robert J. Hard and C. Britt Bousman

5. Name and location of sponsoring agency: City of San Antonio Convention Center Expansion Office, P. O. Box 839966, San Antonio, Texas 78283-3966

6. Texas Antiquities Permit No.: 1776

7. Published by the Center for Archaeological Research, The University of Texas at San Antonio, 6900 N. Loop 1604 W., San Antonio, Texas 78249-0658, 1998

A list of publications offered by the Center for Archaeological Research is available. Call (210) 458-4378; write to the Center for Archaeological Research, The University of Texas at San Antonio, 6900 N. Loop 1604 W., San Antonio, Texas 78249-0658; e-mail to car@lonestar.utsa.edu; or visit CAR's web site at http://www.csbs.utsa.edu/research/car/index.htm. 


\begin{abstract}
In 1997, the Center for Archaeological Research (CAR) of The University of Texas at San Antonio (UTSA) conducted archaeological investigations for the city of San Antonio in conjunction with construction activities for the Henry B. Gonzales Convention Center Expansion Project in downtown San Antonio. This project included monitoring of mechanical excavations, Gradall testing in selected areas, and mitigating one structure foundation. Through these efforts, 25 post-1850 historic features were identified and recorded.
\end{abstract}




\section{Contents}

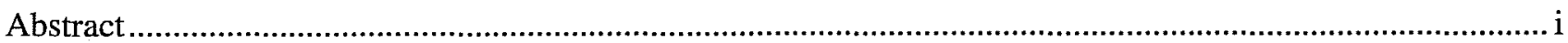

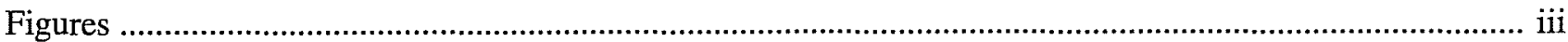

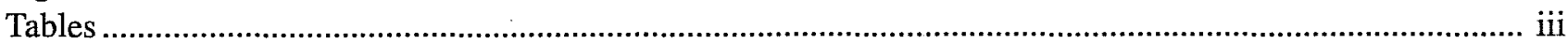

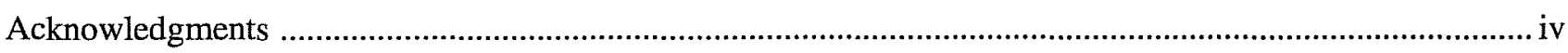

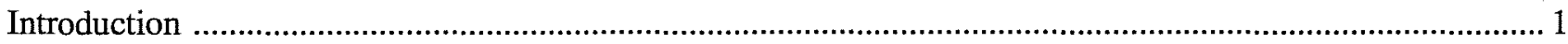

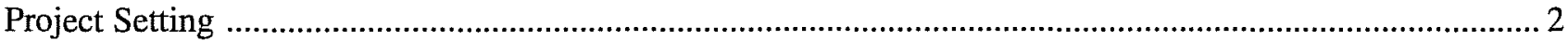

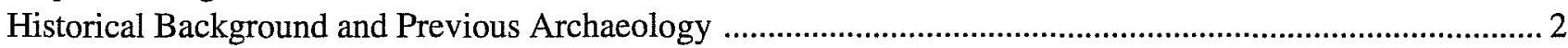

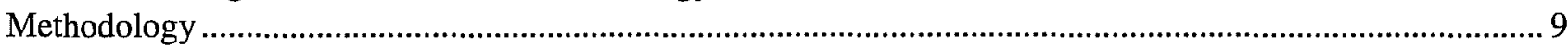

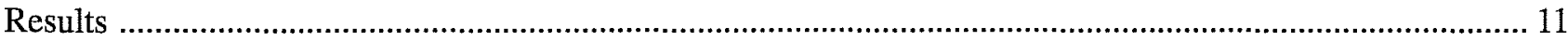

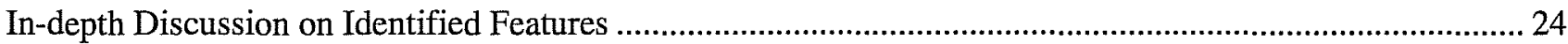

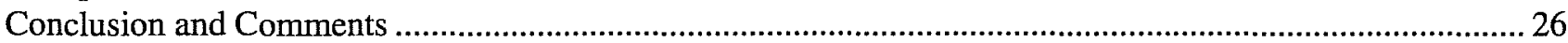

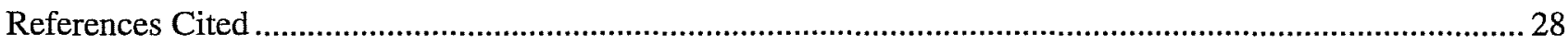

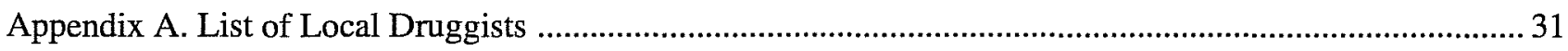

Appendix B. Architectural Observations of Subsurface Foundation Feature 6

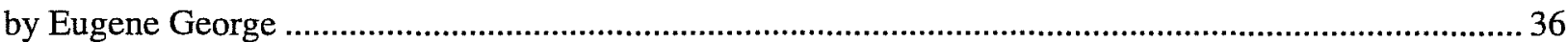

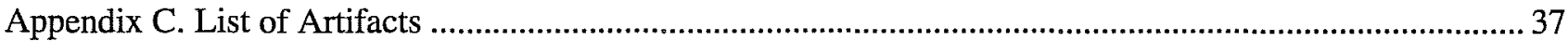




\section{Figures}

1. Project Location 1

2. Cross section of soils in the thermal-lines tunnel trench beneath the demolished HemisFair Arena ....... 2

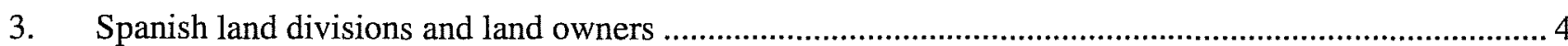

4. Nineteenth-century lot and block designations within the project area ........................................... 6

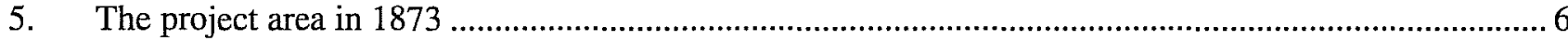

6. Project area showning the relocation sites for the three historic buildings, the route of the thermal-lines trench, CAR Gradall trenches, and the expansion footprint ................................... 7

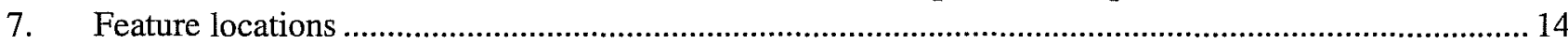

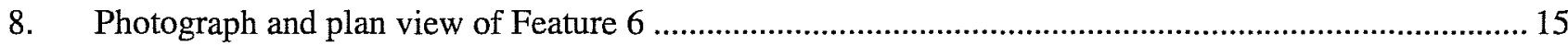

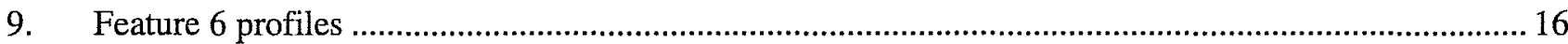

10. 1856-1865 U.S. Army belt buckle found in mortar in Feature 6 foundation ..................................... 17

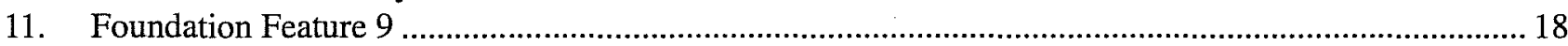

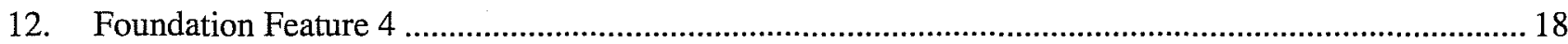

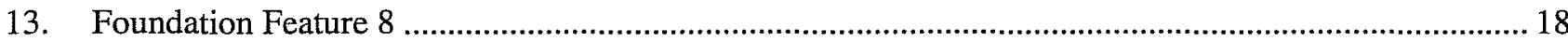

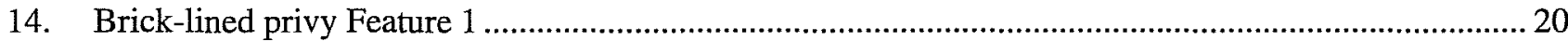

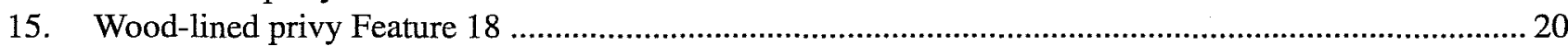

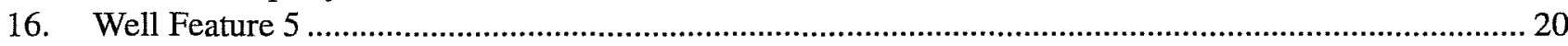

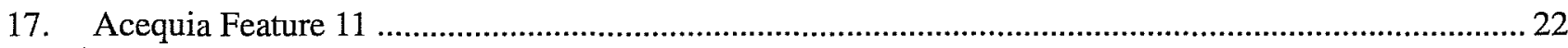

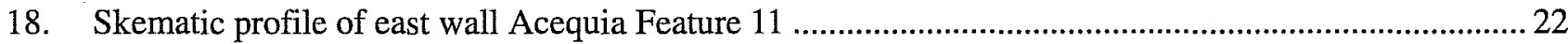

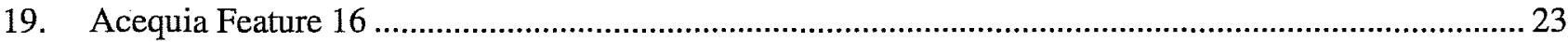

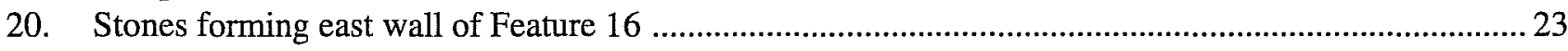

\section{Tables}

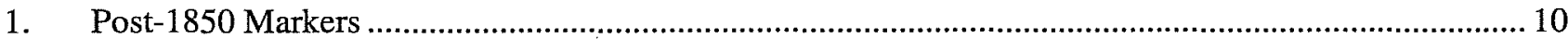

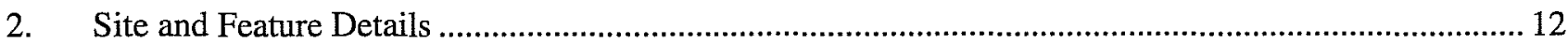

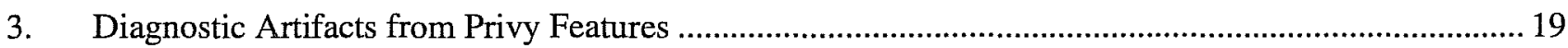

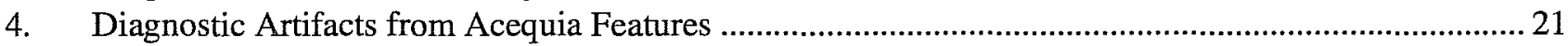

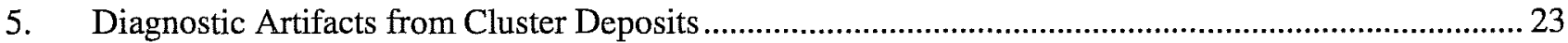




\section{Acknowledgments}

The authors wish to extend our appreciation to the numerous companies and individuals that assisted in the completion of this project. Of utmost importance are City of San Antonio Convention Center Expansion staff members Marc Kimble and Laura Lara who provided the support necessary to allow us to successfully interact with the various contractors on this project. We would also like to acknowledge the following individual contractors and crews with whom we worked most closely and who, through their interest and cooperation made this a project enjoyable. These contractors are: Rusty Chalk, REC Industries, Inc. (thermal-lines installation); Chuck Mayburry and Calvin Brown, M\&M Contracting of Texas, Inc. (expansion footprint excavations), Benito Quintanillo, Cortes Contracting, Inc. (sewer-lines installation); Jim Arnold, Clark/JT (general contractors for Phase IB), and Gabriel Sagredo, Aaron Construction (our Gradall operator). We would also like to thank Dale Bransford of the City of San Antonio Parks and Recreation Department for the loan of equipment and operators during investigations of the Feature 6 foundation. A special thanks is extended to Kevin Sedlak with ATC Environmental Consultants for sharing accommodations and equipment during this project. As always, the production staff at the Center for Archaeological Research, editors Marcie Renner and William Bishel and illustrators Bruce Moses and Chris Butler, made this finished product possible. 


\section{Introduction}

In 1997 the Center for Archaeological Research (CAR) of The University of Texas at San Antonio (UTSA) conducted a multi-phase archaeological investigation for the city of San Antonio in conjunction with construction activities for the Henry B. Gonzales Convention Center Expansion Project in HemisFair Park in downtown San Antonio (Figure 1). This project included monitoring of ground preparations at relocation sites for three historic structures being moved out of the expansion footprint, monitoring of trenching activities for the installation of $2,000 \mathrm{ft}$ of thermal and chilled-water lines to service the new facility, Gradall testing in selected areas of the park prior to full-scale mechanical excavation, monitoring of the excavation for realignment of Bowie Street, and monitoring the excavation of the $800,000 \mathrm{sq} \mathrm{ft}$ building footprint and associated utility trenches. Through these efforts, 27 post-1850 historic features were identified and recorded, including one historic foundation which was partially mitigated.

Prior to initiation of this project, CAR conducted two archival and archaeological assessments of the area to be impacted by the Convention Center expansion for the city of San Antonio (Johnson and Cox 1995; Johnson et al. 1997). Three major points of interest are clear from these summaries of previous archaeological work in downtown San Antonio: 1) the majority of our current information comes from numerous investigations of late nineteenthand early twentieth-century domiciles and neighborhoods; 2) with the exception of Spanishcolonial sites, very few historic sites pre-dating the 1870 s have been investigated; and 3) because of the rich and varied history of the city, any downtown area has the potential for containing significant archaeological deposits. The authors concluded that while the 1966-1968 construction activities related to HemisFair undoubtedly destroyed many of the historic structures, other historic foundations and artifact scatters may actually have been protected by filling and berming during landscaping activities in the area.

Based on this assessment, a scope of work was designed for this project in consultation with the Texas Historical Commission (THC) which called for documenting the presence of historic features and artifact deposits, recording their locations, and

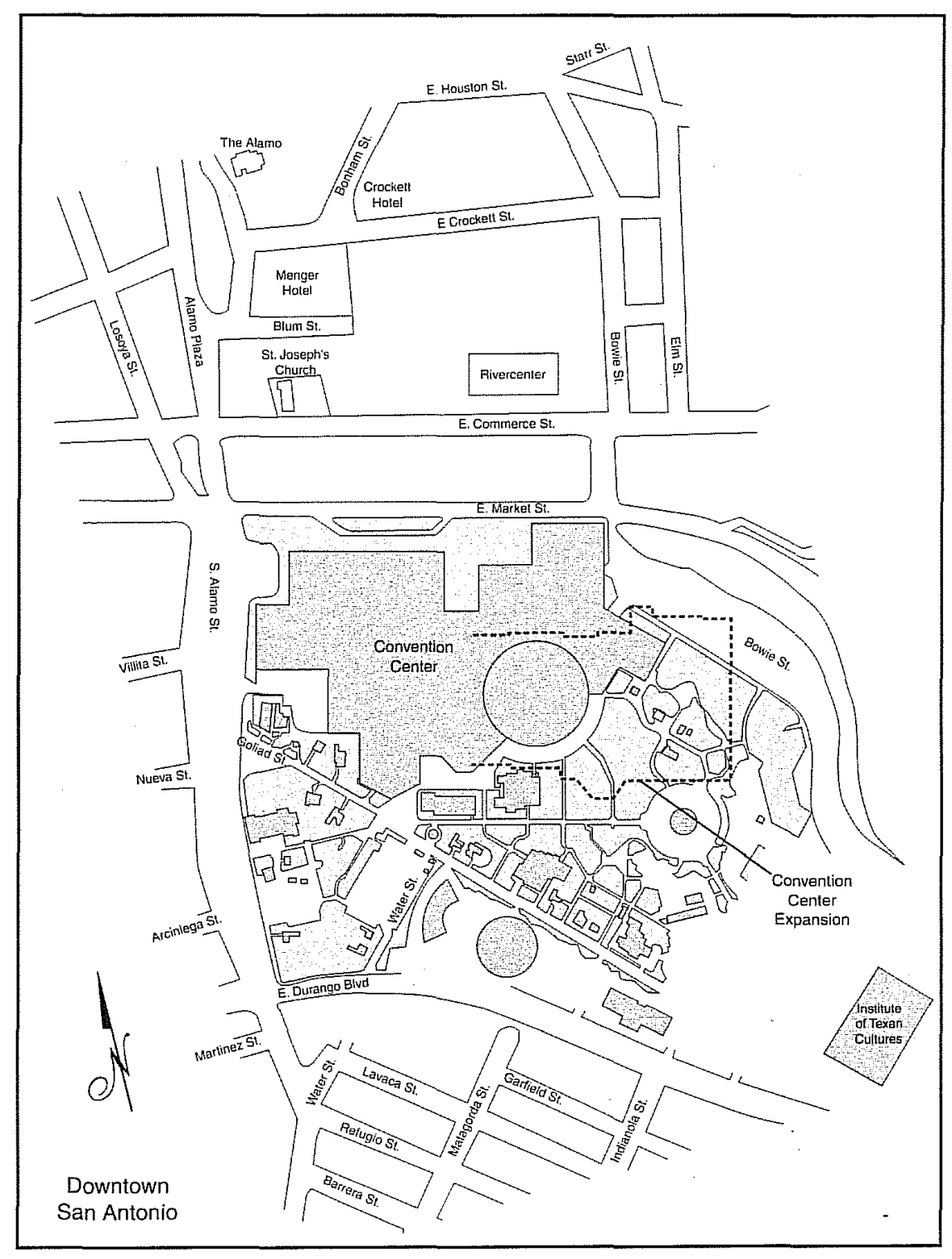

Figure 1. Project Location 
assessing their age. For the purposes of this project, THC defined significant archaeological deposits necessitating work stoppage for further investigation as any intact deposit predating 1850 or "unique or rare" deposits postdating 1850 . This project was conducted under Texas Antiquities Committee Permit No. 1776. Investigations were conducted by CAR archaeological research associates Cynthia L. Tennis and I. Waynne Cox. Co-principal investigators for the project were R. J. Hard and C. Britt Bousman, respectively CAR director and associate director. Field notes, archival information, and artifacts are curated at the CAR laboratory.

\section{Project Setting}

The project area is located in downtown San Antonio where the upper level soils, as described by Taylor et al. (1991) are dominated by Houston Black series, which consists of dark gray to black clayey soils that are calcareous. The surface layer varies from 34-38 inches in thickness and has a firm, blocky structure. The subsurface layer is from $12-20$ inches thick and is gray or dark gray clay with grayish-brown or olivebrown streaks (Figure 2). Both of these layers crack when dry and swell when wet. These upper soils are situated on the Quaternary-aged Fluviatile Terrace Deposits formation, which is predominately composed of gravel, limestone, dolomite, and chert. This strata was encountered at depths $4-17 \mathrm{ft}$ below the surface in geotechnical test borings drilled in the project area by ATC (1996). At depths 13-24 ft below the surface, tan and gray clay representing the underlying Cretaceous Taylor Formation was encountered. Groundwater was encountered in eight of the ten monitor wells drilled by ATC at depths between 12.8 $23.58 \mathrm{ft}$ below the surface. The climate of the area is defined as modified subtropical, with hot summers and cool winters. January has the coldest average temperatures $\left(62.3^{\circ} \mathrm{F}\right)$ while August has the highest average temperature $\left(94.2^{\circ} \mathrm{F}\right)$. Yearly rainfall averages 27.89 inches and the growing season in the southern part of Bexar County is 275 days (Taylor et al. 1991).

\section{Historical Background and Previous Archaeology}

Research into the previous archaeology and archival history of the project area was conducted under



Figure 2. Cross section of soils in the thermal-lines tunnel trench beneath the demolished HemisFair Arena. Looking south. 
separate permits during the planning stage of the convention center expansion. This information has been published separately and is available in Johnson et al. (1995; 1997) and Cox and Fox (1983). Additional information on previous archaeology in downtown San Antonio and in-depth information on the history of the neighborhoods just to the east of project area can also be found in Bousman et al. (1995) and Perez Associates et al. (1997). The interested reader is referred to these reports for a detailed accounts of the multifaceted history of downtown San Antonio. Aside from a brief summary of the general history of the city, the background section of this report focuses on the information that most directly pertains to the current project area.

\section{Prehistoric Period}

The modern metropolitan San Antonio area has been occupied by various cultural groups for more than 10,000 years. Prehistoric sites ranging in age from the Paleoindian period (9000-6000 B.C.) to the Late Prehistoric period, which ended with the arrival of the Spaniards, have been identified along the creeks and rivers in northern and southern Bexar County. However, perhaps because of the early and continuous development along the San Antonio River, our knowledge of prehistoric occupations in the center of the county is limited. With the exception of the St. Mary's Hall site (41BX229), a possible Paleoindian site excavated by a UTSA field school in 1977 (Hester 1978), a Middle Archaic cemetery site (41BX1) at Olmos Dam (Lukowski 1988), and human remains that date to the Late Prehistoric period recovered from 41BX917 in La Villita (Tennis 1994), the prehistoric past of downtown San Antonio remains unknown.

\section{Historic Period}

The Historic period in the New World generally begins with the written accounts produced by the Spaniards and other Europeans upon their arrival in this hemisphere. These early accounts tell of hundreds of small, independent Native American groups occupying the south Texas area (Campbell and Campbell 1985:1).
These bands of hunters and gatherers may have represented as many as six major language groups including the Coahuiltecans. The Payaya, one of the Coahuiltecan-speaking groups, are described in the 1691 eyewitness account of a native settlement along the San Antonio River within the present city limits (Campbell and Campbell 1985:7-8).

Although Spain initially recognized the Rio Grande as the northern boundary of New Spain, pressures by French explorers in the late seventeenth century prompted the Spanish to establish early missions in far East Texas. It wasn't until 1718 that Don Martín de Alarcón was appointed the first Spanish governor of Texas and together with Father Antonio de San Buenaventura y Olivares was sent to establish a mission, presidio, and villa on the San Antonio River (Habig 1977:20). Neither the site of the original Mission San Antonio de Valero "near the first spring, half a league from a high ground and adjoining a small thicket of live oaks" (Hoffmann 1938:318) nor the second "little fortification" destroyed by a hurricane in 1724 (de Paredes 1727) have been identified. Mission San Antonio de Valero (later to become known as the Alamo) was thus established in its third and present location in 1724 .

The Acequia del Alamo was established to supply water to this mission and irrigate the surrounding agricultural lands. Emanating a short distance below the headwaters of the San Antonio River in presentday Brackenridge Park, the canal ran approximately 3.5 miles before re-entering the river at the large bend just south of the mission. Later branches to the east and south of the Alamo acequia would increase the total length of the canal to approximately 10 miles, bringing additional land, including the current project area, under irrigation (Figure 3).

These lands remained the property of Mission Valero until 1793, when the mission compound and surrounding irrigated lands were deeded to Spanish residents of the mission and to the Adaesaños, settlers from the community of Los Adaes forced to seek refuge in San Antonio when Spain withdrew from east Texas in 1774 (Figure 3). The current project area involves two of these suertes, or tracts of land, granted to Adaesaños José Alcale and Ramon de los Fuentes 


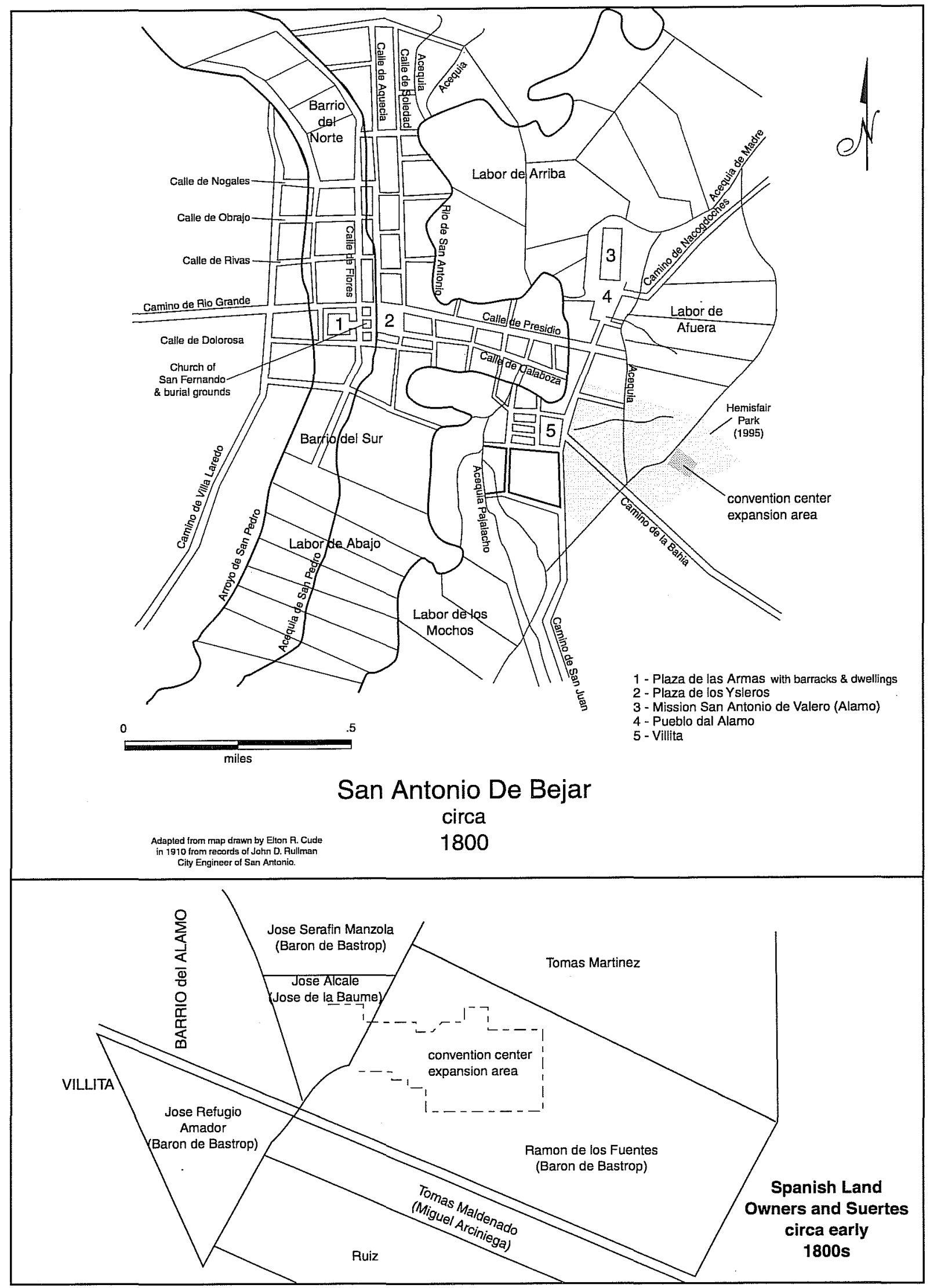

Figure 3. Spanish land divisions and land owners. 
(Chabot 1937:216; City Engineer's Map 1916, copy on file at CAR).

In the decades that followed, San Antonio was involved in much of the political unrest between Mexico and Spain. In 1824, three years after Mexico became an independent nation, the new Federal Constitution of Mexico merged the provinces of Texas and Coahuila into one state with Saltillo as the capital. The following year, Texas became a separate department and San Antonio de Bexar became the new capital. Twelve years later, San Antonio was the site of the famous Battle of the Alamo which paved the way for the 1836 Texan defeat of the Mexican army and the beginning of the Republic of Texas (see Johnson et al. 1997 for more detail).

Political unrest and military incursions by Mexican troops did not completely cease until Texas was annexed by the United States in 1844 . The ensuing influx of people from the southern United States and Europe following statehood prompted land speculators to purchase large tracts of land for division into smaller lots for development.

\section{Project Area}

From the establishment of the Mission San Antonio de Valero until the mid-nineteenth century, the New City Blocks (NCB) comprising the project area were primarily agricultural lands with no structures or improvements (Johnson et al. 1997). As shown in Figure 4, the majority of the project area encompasses portions of NCB 688, 689, 692, 693, 873, and 874 . This property, east of Water Street, was amassed by land speculator Joseph Beck in 1848 and subdivided into lots and blocks to form the community known as Beckville (see Johnson et al. 1997). Early Lot ownerships for all of Beckville, including the ones within the project area, are traced in Appendix B of Johnson et al. (1997).

The deed records from 1845 describe the extent of a certain tract as being "bounded on the west by the main ditch, on the east by the lands known at the time of purchase by the Baron de Bastrop as Royal Lands, on the north by other lands at that time owned by Baron de Bastrop" (BCDR C2:121). A more detailed description of this same tract was given from an 1848 transaction. This record states that the land was

bounded west by the main ditch extending from Goliad Road, up said ditch to an old stone dam pointed out by José Antonio de la Garza who formerly owned said tract of lands bounded south by the Goliad Road extending 440 varas and running northeast as designated by the present line of fence thence west to the said dam (BCDR, G1:447).

The original land that was to become known as Beckville was once the suerte of Ramón de los Fuentes (see Figure 7). The Spanish government granted him this tract in 1794. In November 1808 he sold the parcel to José Antonio de la Garza, the same man who pointed out the location of the old stone dam on the property's northwest corner. Eight years later, de la Garza sold the real estate to the Baron de Bastrop. In October 1829, Philip Dimmitt purchased the land from the heirs of Bastrop. After Dimmitt's death, William E. Jones acted as administrator for Dimmitt's heirs and sold the old suerte to Volney E. Howard at a public auction in June 1845. Next in the line of owners was Matt Evans. Evans bought the old suerte in April 1848 and then quickly resold it to Joseph Beck in October (BCDR C2:121, G1:447, N1:226). Until this time the land had remained intact as one large, undeveloped parcel. Joseph Beck took the first steps to making this a residential area: he had the suerte divided into blocks and town lots.

In 1848 the land was surveyed and subdivided into lots and city blocks by the deputy city surveyor, W. S. Smythe. It was common practice to describe the limits of a parcel by fixed objects and by the neighbors adjacent to the property. Although the fixed objects were usually natural, they could also be large manmade objects. Hence, early records are replete with references to trees, boulders, waterways, stone dams, fence lines, fence posts, and the like. Spanish land measurements were still in use throughout most of the nineteenth century and were reflected in the deed records of the time. The vara-equivalent to about 33 inches-was the main unit of measurement. A square vara equaled 7.7 square feet, 0.86 square yards, or 


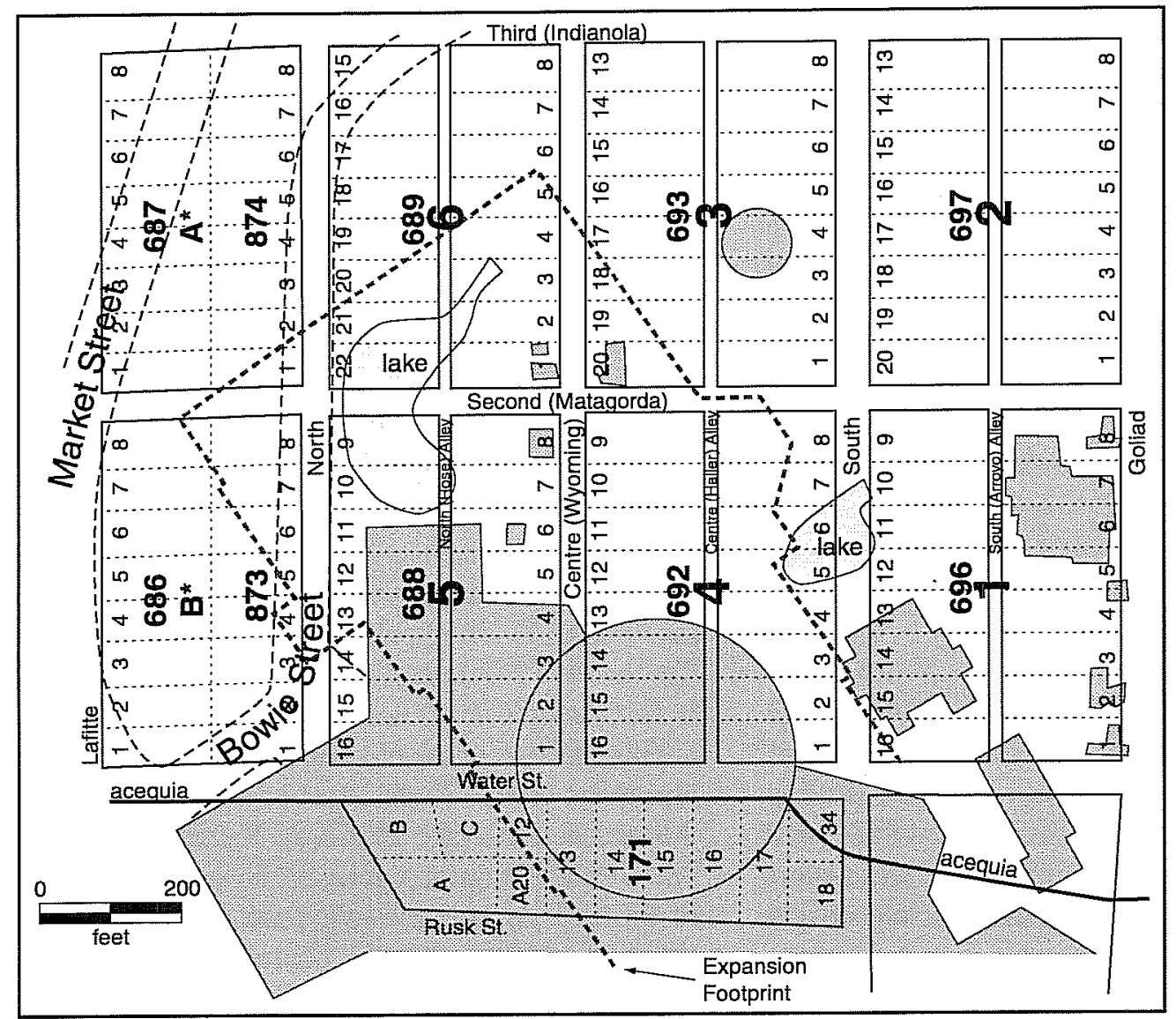

Figure 4. Nineteenth-century lot and block designations within the project area. Looking east.

Figure 5. The project area in 1873. From Koch's Bird's Eye View of the City of San Antonio. Looking east.

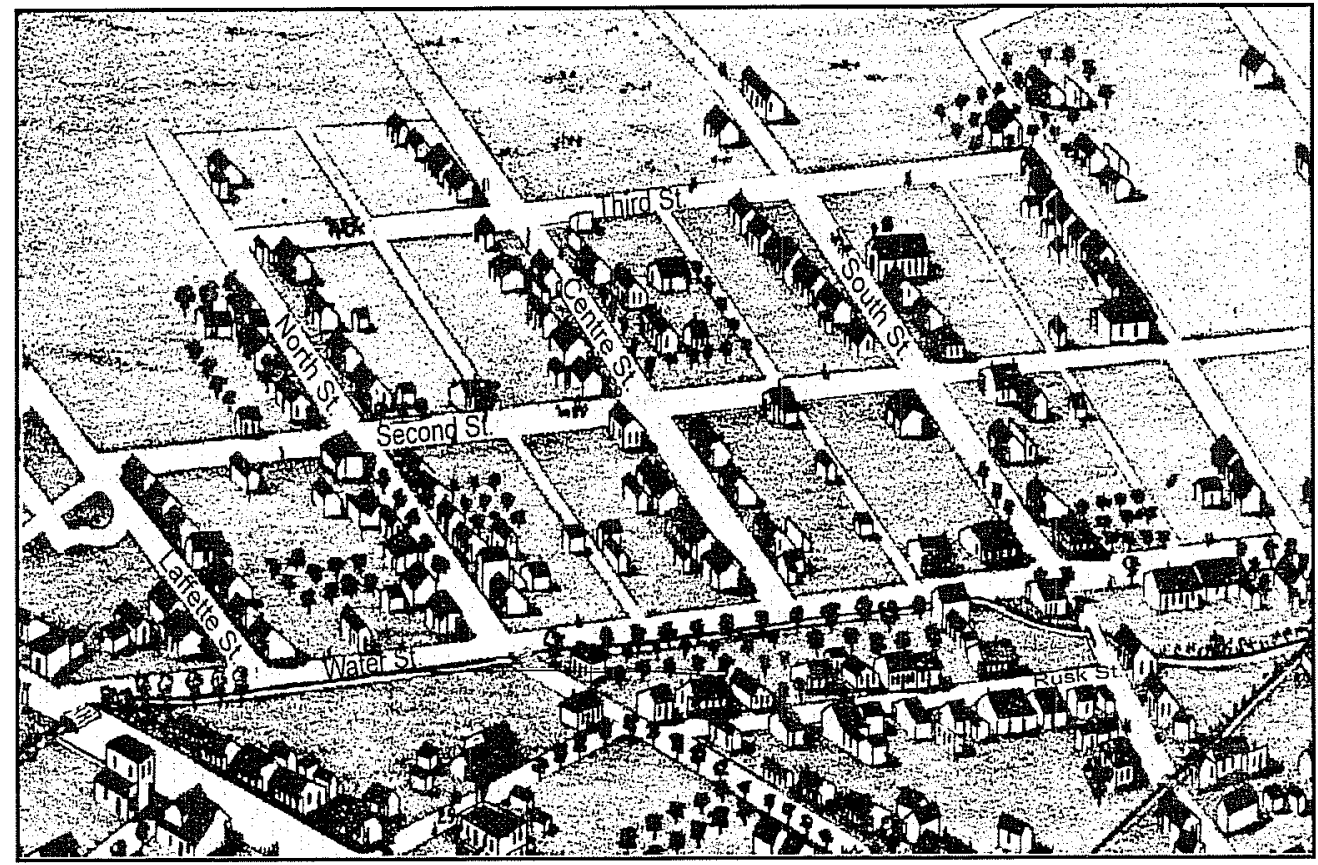




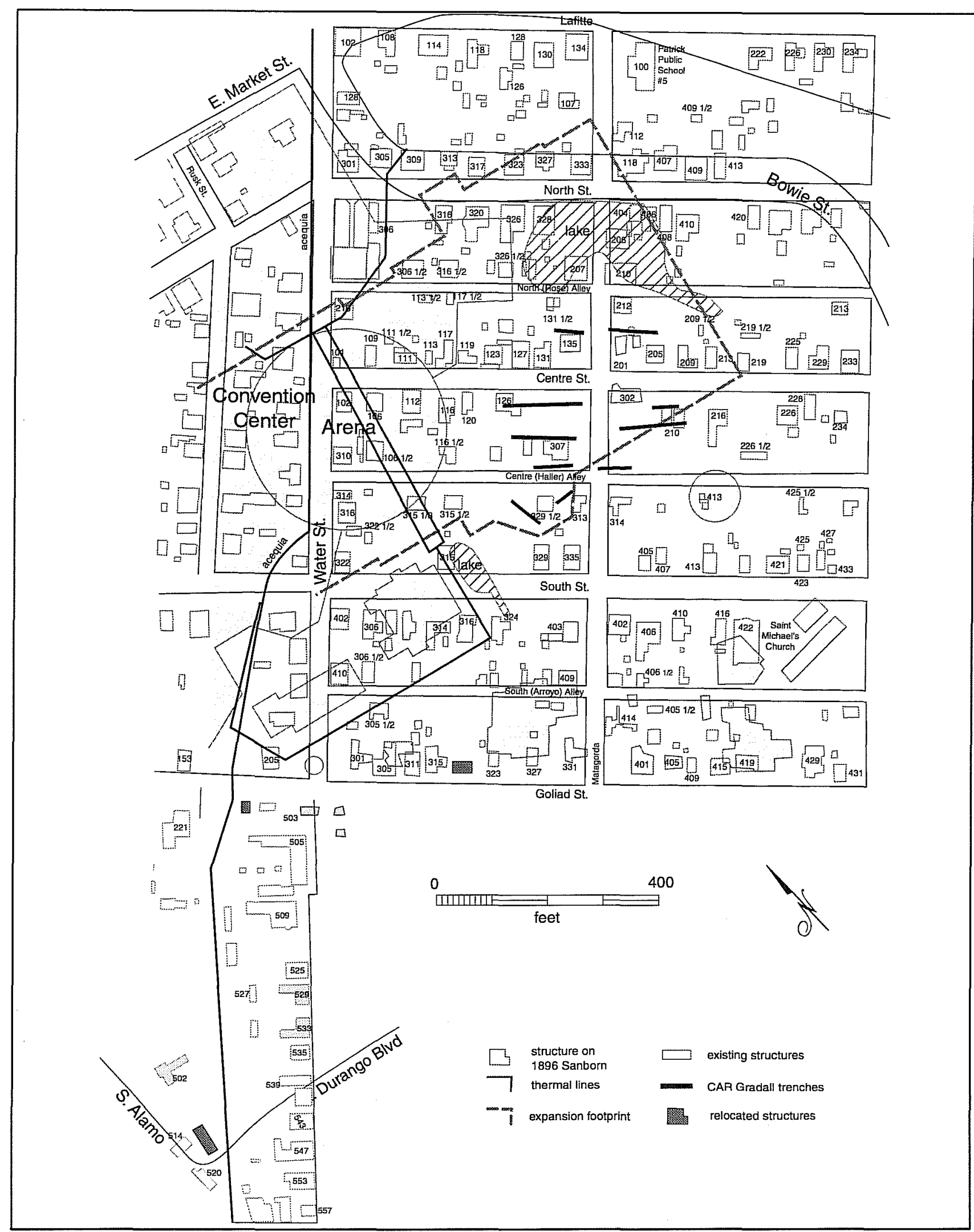

Figure 6. Project area showing the relocation sites for the three historic buildings, the route of the thermal-lines trench, CAR Gradall trenches, and the expansion footprint. 
0.00018 acres, while a labor had $1,000,000$ square varas or 177.1 acres (Dobkins 1959:2).

Most Beckville lots measured 20 varas $(55.5 \mathrm{ft}$ ) along the front and 50 varas (139 ft) in depth, with an area of 1,000 square varas. Most blocks were identical, containing 16 lots. Eight lots fronted a north side street, while a like number of tracts fronted a street on the block's south side. The entire block measured 160 varas (444 $\mathrm{ft}$ ) east to west along its front by 110 varas (305 ft) in depth. An alley 10 varas $(28 \mathrm{ft}$ ) wide ran east to west through the center of the blocks. A few parcels were located on fractional blocks and were the exceptions to these standard sizes.The 16 lots on CB 873 and CB 874 and the four lots east of Third Street were only 40 varas in depth instead of the usual 50 varas (see Figure 4 ).

After the Smythe survey, Ramón de las Fuentes's old suerte became 130 Beckville lots shown in Figure 4. New streets, blocks, and alleys formed by the survey were named and numbered. Beckville block designations were subsequently converted to the city block numbers. Likewise, in time, some of the street names were also changed. In March 1881, Second Street became Matagorda and Third Street was changed to Indianola (City Directory 1881). Later, Centre Street was renamed Wyoming. Just prior to HemisFair 1968, old Beckville was bounded on the south by Goliad Street, west by Water Street, north by North Street, and east by Indianola Street. Beckville's narrow alleys were also eventually named. Rose Alley was between North and Wyoming streets. Haller Alley ran between Wyoming and South streets, while Arroyo Alley paralleled South and Goliad. A building that fronted an alley usually had a separate address from the structure that faced the main avenue. Beckville contained city blocks $688,689,692,693,696,697$, 873 , and 874 .

A stone dam described by José Antonio de la Garza as forming the northern boundary to city blocks 873 and 874 in Beckville would have been located near the intersection of present day Bowie and East Market streets (Figure 4). It probably fed a small lateral or irrigation ditch that branched off from the Alamo Acequia Madre. A map of San Antonio circa 1800 (see Figure 3) also shows two laterals that would have been on the west side of Water Street. The Beckville ditch may have been another independent ditch or possibly an extension of one of these existing laterals. A few deed records do refer to an irrigation ditch in Beckville. According to some records, the Beckville ditch not only provided water but also established the northern boundary line for the community (BCDR P2:472, P2:526).

Volney Howard had purchased the entire Fuentes suerte for only $\$ 100$ at the auction in 1845. Joseph Beck paid Matt Evans over $\$ 600$ for the suerte just three years later (BCDR G1:447). This was a fair sum of money in 1848. Nevertheless, as a business venture, there was the opportunity to make a large profit. Early transactions in Beckville show that the lots were selling for $\$ 75$ to $\$ 125$ each. If all 130 lots were quickly sold at an average of only $\$ 100$ apiece, Joseph Beck would have received about $\$ 13,000$. This meant a profit of around $\$ 12,500$ above his initial investment. However, the new neighborhood got off to a slow start and Beck did not sell the last of these tracts until June 1860. It took nearly 12 years for Joseph Beck's name to finally drop from the roll of Beckville's real estate transactions. Shortly after the land was subdivided, Beck encountered a major, unforeseeable obstacle to his plans: cholera.

Cholera, a disease usually spawned by contaminated water supplies, ravaged San Antonio in 1849 and again in 1866. Drinking water was obtained from shallow wells and the acequias until the new water works began pumping water from the river in 1878 (Ramsdell 1985:52). Until that time, the city's water supply regularly became contaminated from outhouses. Besides cholera, typhoid fever and malaria were also prevalent (Ramsdell 1985:45). Before the 1849 epidemic ran its course, the cholera plague claimed more than 500 lives. As a result, many residents fled the city just as Beckville was getting started (House 1968[1949]:106). Nevertheless, this was only a temporary setback. The community overcame the plague of 1849 and many other hurdles in the years that followed.

The following newspaper announcement, which appeared in an 1868 edition of the San Antonio 
Express, reflects the neighborhood's status 20 years after Beck's initial survey.

For Sale At Public Auction By David Friedlander \& Co. Improved City Property. Will be sold on Friday, July 17 th, at 10 o'clock, A.M. In front of the premises, the House and Lot of Ground situated at the north-east corner of Goliad and Second streets, east of Alamo ditch. The house is of hard rock, with a cellar attached, and a fine well of water. The property is in a pleasant neighborhood, well surrounded by excellent improvements and in one of the most thriving and prosperous portions of the city. Terms stated on day of sale. Act of sale including Internal Revenue stamps at expense of purchaser. For further information apply to DAVID FRIEDLANDER \& Co. [SAE 4 July 1868, emphasis in the original].

By 1868 most of the project area was indeed a pleasant and prosperous neighborhood. The house and lot in the above newspaper announcement was located on Lot 1 of Beck Block 2, at 401 Goliad Street. Known as the Richter house, it still stands on the same corner.

NCB 171, east of Water Street, was not part of the Beckville development (Figure 4). This block was originally the extreme easterly portion of the Joseph de la Baume property (Figure 3). All of NCB 171 was purchased by Garret P. Post and later resold as individual city lots. The exception to the above is Lot 34 in the extreme southeast corner of this block. Because this lot was on the east side of the acequia, it was part of the tract purchased by Joseph H. Beck in 1848 (Johnson et al. 1997).

A growing multicultural residential district led to a variety of small businesses and churches. The city also acquired lots for schools, fire stations, and other services to support the neighborhood. Although research into the Bexar County Deed Records (BCDR) indicate that the majority of these lots were not sold until after 1855 (Johnson et al. 1997), by the 1870 s, Beckville was a well-established community. In 1873, Augustus Koch preserved a unique glimpse of this area in his drawing entitled
Bird's Eye View of the City of San Antonio (Figure 5 ). By this time, many homes had been constructed on the lots along the main streets within the project area.

\section{Methodology}

A methodology was designed to fit within the pre1850s significance parameters established by THC for this project. These guidelines allowed for the inspection and recording of features associated with archivally documented post-1850 development of Beckville and the surrounding areas while providing a safeguard against disturbance to unexpected deposits from the Spanish-colonial and Republic of Texas periods.

\section{Assessment and Recording Protocol}

Construction projects of the scale of the Convention Center Expansion require an immense amount of coordination between and close adherence to scheduling and completion deadlines by all the contractors involved. Therefore, it was necessary to design a protocol that would allow for accurate and comprehensive assessment and recording of archaeological features and artifact concentrations while minimizing interference and delays to the project. Based on THC's definition of significant archaeological deposits necessitating work stoppage for further investigation, parameters were established to assist in quickly differentiating between deposits predating and postdating 1850 in the field. Previously compiled archival records were consulted for dates of occupancy. An enlargement made of the project area from Koch's 1873 Bird's Eye View of the City of San Antonio was used to identify structures and features that might be encountered from that time period (Figure 5). The current project-area configuration was overlaid on the 1896 Sanborn map of the area for orientation and identification of later structures (Figure 6). Previously identified maker's marks (Tennis 1997), a list of local druggists (Appendix A), and/or the presence of artifact types and construction materials listed in Table 1 were used to assign features and 
Table 1. Post-1850 Markers

\begin{tabular}{|l|l|}
\hline \multicolumn{1}{|c|}{ Post-1850 } & \multicolumn{1}{c|}{ Reference } \\
\hline Wire nails & Fontana (1965) \\
\hline Yellow brick & Steinbomer (1983) \\
\hline Ironstone & Miller (1991) \\
\hline Albany or Bristol-glazed stoneware & Greer (1981) \\
\hline Decal decorated whiteware & Durrenberger (1965) \\
\hline Band \& Line decorated whiteware & Miller (1991) \\
\hline
\end{tabular}

associated artifact concentrations to the post- 1850 period.

Portions of identifiable historic features exposed during trenching activities were recorded on Feature Forms listing approximate spatial provenience and associated address when possible, dimensions, depth below current surface, bottom depth where applicable, and artifacts collected and/or noted. Photographs were taken and the feature was plotted on a scaled field map. Deposits in the immediate area were examined for diagnostic artifacts which, if present, were collected and used to assess the age of the feature or, in the case of privies, wells, or cisterns, the approximate time period of the fill episodes.

\section{Phase I Monitoring}

During Phase I, two segments of the construction project, which were conducted simultaneously, were monitored. These activities involved ground preparations at relocation sites for three historic structures being moved out of expansion footprint and excavations for the installation 2,000 linear $\mathrm{ft}$ of steam and chilled water lines. These lines begin on the north side of Bowie Street, extend south through areas previously occupied by the Arena Parking Garage and HemisFair Arena, continue west in front of the Universidad Nacional Autonoma De Mexico (UNAM) and the Mexican Cultural Institute, and turn north again to end at the entrance to the South Banquet Hall of the existing convention center (Figure 6).
With the exception of the section of trench beneath the demolished arena, thermal-line trenches were 7.5$8 \mathrm{ft}$ wide and 3-7 ft deep. Beneath the arena, the trench was $18-20 \mathrm{ft}$ in depth with sloped sides that extended $20 \mathrm{ft}$ on either side of the main excavation. At the three historic structure relocations sites, four to six inches of soil were removed by a Bobcat to level the foundation pads. Utility trenches within the pads were hand excavated to a depth of 24 inches.

\section{Gradall Trenching}

Prior to initiation of the main construction phase, Phase IB, 14 Gradall trenches were excavated in undisturbed areas of HemisFair Park within the building footprint to search for pre-1850 deposits (Figure 6). Gradall trenches were approximately $5.5 \mathrm{ft}$ wide and were excavated to a minimum depth of four $\mathrm{ft}$ below the surface, except where buried utilities were encountered. Because of Gradall mobility limitations, trenches were excavated in sections averaging $10 \mathrm{ft}$ in length. Soil was removed in two- to three-inch levels. The excavation of each trench was monitored at all times by a two-person team. One person monitored the excavation for features while the other monitored the backdirt for artifacts. As a safety measure, open sections of the trench were backfilled at the end of each day.

Much of the park, however, proved inaccessible due to existing sidewalks, landscaping, and maintenance roads which would remain in use in the public park until the next phase of construction began. Other areas of concern beneath the parking garage and Bowie 
Street would remain covered until full-scale excavation of the expansion footprint began. Plans were therefore altered to include spot monitoring of these unreachable areas during Phase IB excavations.

\section{Phase IB: Expansion Footprint Excavation and Bowie Street Realignment}

The final stage of archaeological investigations for the Convention Center Expansion project involved monitoring of excavations for the building footprint and the realignment of portions of Bowie Street on the northern edge of the building. Excavations were carried out by a 235 and a 330 CAT trackhoe with 5 $\mathrm{ft}^{3}$ buckets. Across 90 percent of the 800,00 sq. $\mathrm{ft}$. footprint, soil was removed to a subgrade depth of $649 \mathrm{ft}$ amsl. (four to nine feet below the modern surface), a depth that in most cases resulted in the removal of the entire surface and subsurface layers of Houston Black clay. The area was then back filled to $652 \mathrm{ft}$ amsl with excavated soils and topped with 2.5 $\mathrm{ft}$ of construction base. Along the eastern edge of the footprint, where the expansion will join the existing convention center, excavations went to $35 \mathrm{ft}$ below the existing surface. The realigned section of Bowie Street, at the northern edge of the project area, was excavated to a depth two to three feet below the surface. (Figure 6).

\section{Structure Mitigation}

During Phase I, portions of an unidentified limestone foundation were exposed in the thermal-lines trench at the northwestern edge of the project area adjacent to the existing parking garage. Because the location of this foundation did not match structures shown on the 1896 Sanborn map and no time-diagnostic artifacts were immediately present, work in this area was stopped pending an assessment of the need for further investigation. After a site visit by Mark Denton from THC and consultation with the city's project managers, it was decided to trace and record the extent of the remaining foundation and to fully document portions of the foundation to be directly impacted by installation of the thermal lines.
With the aid of a backhoe and operator from the City of San Antonio Parks and Recreation Department and a trackhoe and operator supplied by the project contractor, modern fill was removed from the surface to reveal the limits and configuration of the foundation. After a thorough examination of the exposed portions and the surrounding soils, it was determined that the soil inside the foundation walls represented the area below the historic living surface and was sterile. This soil was mechanically removed to the depth of the foundation base. Foundation stones were then fully exposed by hand, photographed, planned, mapped, illustrated, videotaped, and the structure location was plotted by EDM. Because the entire eastern wall and portion of the northeast and southeast corners were in the direct path of the thermal lines trench, both the interior and exterior of these sections were exposed and documented. Subsequent demolition activities were monitored and mortar between the layered stones was inspected for diagnostics.

\section{Results}

Twenty-six historic features were exposed during the various phases of the project. Details of these features, which include two sections of the Alamo Acequia, two brick- and one wood-lined privy, four trash pits, two artifact scatters, two wells, 11 limestone foundations, and one yellow-brick manhole are given in Table 2 and their locations are plotted in Figure 7. As no actual records of home construction dates were made, the "Probable Construction Date" and "Owner" at the time of construction used in Table 2 are based on length of time between title transfers and the selling prices of the property found in the Bexar County Deed Records (BCDR). State trinomial numbers 41BX1296, 41BX1297, and 41BX1298 were assigned to the three NCBs now beneath the Convention Center where historic structures and deposits were identified. Two trinomial numbers, 41BX1299 and 41BX1300 were assigned to historic foundation remnants discovered during monitoring activities away from the building footprint (Figure 7 and Table 2).

All features are associated with residential use of the area after 1850 . While archival information indicates some of the structures may have been in use during 
Table 2. Site and Feature Details

\begin{tabular}{|c|c|c|c|c|c|c|c|}
\hline Site \# & Feat.\# & Feature Type & Dimensions and Depth BS & Diagnostics & $\begin{array}{l}\text { Associated Historic } \\
\text { Address }\end{array}$ & $\begin{array}{c}\text { Probable } \\
\text { ConstructionDate }\end{array}$ & Original Owner \\
\hline \multirow{5}{*}{$41 \mathrm{~B} \times 1296$} & 6 & $\begin{array}{l}\text { Limestone } \\
\text { foundation }\end{array}$ & $\begin{array}{l}35 \times 20 \mathrm{ft} \\
3 \text { courses remain } \\
24-56 \text { inches bs }\end{array}$ & $\begin{array}{l}\text { see Feature } \\
\text { discussion }\end{array}$ & $\begin{array}{l}\text { NCB } 688, \text { Lot } 15 \\
106 \text { North St. }\end{array}$ & ca. 1859 & $\begin{array}{l}\text { John Wilkins } \\
\text { (BCDR R1:369) }\end{array}$ \\
\hline & 17 & $\begin{array}{l}\text { Limestone } \\
\text { foundation }\end{array}$ & $\begin{array}{l}8 \mathrm{ft} \text { section, tw o cour ses remained } \\
24-56 \text { inches bs }\end{array}$ & no & $\begin{array}{l}\text { NCB } 688, \text { Lot } 7 \\
\text { Behind } 131 \text { Center }\end{array}$ & ca. 1865 & $\begin{array}{l}\text { Jacob Weitzel } \\
\text { (BCDR T 1:388) }\end{array}$ \\
\hline & 22 & $\begin{array}{l}\text { Limestone } \\
\text { foundation }\end{array}$ & $\begin{array}{l}15 \mathrm{ft} \text { long, one course remained } \\
24-36 \text { inches bs }\end{array}$ & no & $\begin{array}{l}\text { NCB } 688, \text { Lots } 3-4 \\
1131 / 2 \text { North Alley }\end{array}$ & after 1858 & $\begin{array}{l}\text { Rental owned by } \\
\text { Zacheus Golloff } \\
\text { (BCDR G2:309, R2:368) }\end{array}$ \\
\hline & 23 & Trash deposit & $\begin{array}{l}24 \text { inch diameter } \\
24-48 \text { inches bs }\end{array}$ & Table 5 & $\begin{array}{l}\text { NCB } 688, \text { Lot } 13 \\
316^{1 / 2} \text { North Alley }\end{array}$ & ca. 1865 & $\begin{array}{l}\text { Henry Semilinger } \\
\text { BCDR (T 1:463) }\end{array}$ \\
\hline & 25 & Trash deposit & $\begin{array}{l}29 \text { inch diameter } \\
24-54 \text { inches bs }\end{array}$ & Table 5 & $\begin{array}{l}\text { NCB } 688, \text { Lot } 13 \\
316^{1 / 2} \text { North Alley }\end{array}$ & ca. 1865 & $\begin{array}{l}\text { Henry Semilinger } \\
\text { BCDR (T 1:463) }\end{array}$ \\
\hline \multirow{9}{*}{$41 \mathrm{BX} 1297$} & 3 & Brick manhole & $\begin{array}{l}52 \text { inch diameter } \\
36 \text { inches bs }\end{array}$ & no & & & \\
\hline & 4 & $\begin{array}{l}\text { Limestone } \\
\text { foundation }\end{array}$ & $\begin{array}{l}\text { NE corner, } 2 \text { wall sections, } \\
10 \text { and } 4 \mathrm{ft} \text { long, } 3 \text { courses } \\
8-44 \text { inches bs }\end{array}$ & no & $\begin{array}{l}\text { NCB } 692, \text { Lot } 16 \\
102 \text { Center St. }\end{array}$ & ca. 1874 & $\begin{array}{l}\text { Ferdinand Langer } \\
\text { (BCDR 1:343) }\end{array}$ \\
\hline & 5 & Well & $\begin{array}{l}\text { approx. } 40 \text { inches } \\
2-14 \mathrm{ft} \text { bs }\end{array}$ & no & $\begin{array}{l}\text { NCB } 692, \text { Lot } 3 \\
3151 / 3 \text { Center Alley }\end{array}$ & ca. 1868 & $\begin{array}{l}\text { Marie and George Haller } \\
\text { (BCDR U 1:162) }\end{array}$ \\
\hline & 9 & $\begin{array}{l}\text { Limestone } \\
\text { foundation }\end{array}$ & $\begin{array}{l}\mathrm{N} \text { and } \mathrm{E} \text { walls, } 10 \text { and } 12 \mathrm{ft} \text { long, } 7 \\
\text { inches of bottom course remained } \\
38 \text { inches bs }\end{array}$ & no & $\begin{array}{l}\text { NCB } 692, \text { Lot } 11 \\
126 \text { Center St. } \\
\text { (later } 124 \text { Wyoming) }\end{array}$ & ca. 1880 & $\begin{array}{l}\text { Magdalene and Joseph Kohr } \\
\text { (BCDR T: 684) }\end{array}$ \\
\hline & 10 & $\begin{array}{l}\text { Limestone } \\
\text { foundation }\end{array}$ & $\begin{array}{l}35 \mathrm{ft} \text { sections } \\
5-44 \text { inches bs }\end{array}$ & no & $\begin{array}{l}\text { NCB } 692 \text {, Lots } 9-10 \\
307 \text { Matagorda }\end{array}$ & ca. 1894 & $\begin{array}{l}\text { J. A. Mittamann } \\
\text { (BCDR 121:456) }\end{array}$ \\
\hline & 13 & $\begin{array}{l}\text { Brick-lined } \\
\text { privy }\end{array}$ & $\begin{array}{l}3 \times 5 \mathrm{ft} \\
58 \text { inches bs }\end{array}$ & Table 3 & $\begin{array}{l}\text { NCB } 692 \text {, Lot } 43151 / 3 \\
\text { or } 3151 / 2 \text { Center Alley }\end{array}$ & ca. 1868 & $\begin{array}{l}\text { Marie and Geor ge Haller } \\
\text { (BCDR U 1:162) }\end{array}$ \\
\hline & 14 & Trash pit & $\begin{array}{l}3 \mathrm{ft} \text { diame ter } \\
36-72 \text { inches bs }\end{array}$ & Table 5 & $\begin{array}{l}\text { NCB } 692 \text {, Lot } 4315 \% / 3 \\
\text { or } 3151 / 2 \text { Center Alley }\end{array}$ & ca. 1868 & $\begin{array}{l}\text { Marie and Geor ge Haller } \\
\text { (BCDR U1:162) }\end{array}$ \\
\hline & 19 & $\begin{array}{l}\text { Limestone } \\
\text { foundation }\end{array}$ & $\begin{array}{l}10-x-15 \mathrm{ft} \text {, one course remained } \\
48 \text { inches bs }\end{array}$ & no & $\begin{array}{l}\text { NCB } 692, \text { Lot } 11 \\
\text { Behind } 126 \text { Center } \\
\text { (later } 124 \text { Wyoming) }\end{array}$ & ca. 1880 & $\begin{array}{l}\text { Magdalene and Joseph Kohr } \\
\text { (BCDR T 2:684) }\end{array}$ \\
\hline & 20 & $\begin{array}{l}\text { Limestone } \\
\text { foundation }\end{array}$ & $\begin{array}{l}10 \mathrm{ft} \text { section, one cour se remained } \\
36 \text { inches bs }\end{array}$ & no & $\begin{array}{l}\text { NCB } 692 \text {, Lot } 1 \\
322 \text { Water St. }\end{array}$ & after 1863 & $\begin{array}{l}\text { Barbara Weikzonack } \\
\text { (BCDR T 1:26) }\end{array}$ \\
\hline
\end{tabular}


Table 2. continued

\begin{tabular}{|c|c|c|c|c|c|c|c|}
\hline Site \# & Feat.\# & Feature Type & Dimensions and Depth BS & Diagnostics & $\begin{array}{l}\text { Associated Historic } \\
\text { Address }\end{array}$ & $\begin{array}{c}\text { Probable } \\
\text { ConstructionDate }\end{array}$ & Original Owner \\
\hline \multirow{7}{*}{$41 B \times 1298$} & 1 & $\begin{array}{l}\text { Brick-lined } \\
\text { privy }\end{array}$ & $\begin{array}{l}36 \times 47 \text { inches } \\
38.5 \text { inches bs }\end{array}$ & Table 3 & $\begin{array}{l}\text { NCB } 171, \text { Lot } 13 \\
219 \text { Water St. }\end{array}$ & ca. 1877 & $\begin{array}{l}\text { F. E. Grothaus } \\
\text { (BCDR 8:357) }\end{array}$ \\
\hline & 2 & Ar tifact scatter & $\begin{array}{l}20 \mathrm{ft} \text { long, width of trench } \\
27-32 \text { inches bs }\end{array}$ & Table 5 & $\begin{array}{l}\text { NCB 171, Lot } 13 \\
219 \text { Water St. }\end{array}$ & ca. 1877 & $\begin{array}{l}\text { F. E. Grothaus } \\
\text { (BCDR 8:357) }\end{array}$ \\
\hline & 11 & $\begin{array}{l}\text { Acequia } \\
\text { remnant }\end{array}$ & $\begin{array}{l}20 \mathrm{ft} \text { section } \\
3-8 \mathrm{ft} \text { bs }\end{array}$ & Table 4 & & & \\
\hline & 15 & $\begin{array}{l}\text { Limestone } \\
\text { foundation }\end{array}$ & $\begin{array}{l}212 \mathrm{ft} \text { sections, } 2 \text { courses remained } \\
3 \mathrm{ft} \text { bs }\end{array}$ & no & $\begin{array}{l}\text { NCB 171, Lot } 18 \\
238 \text { Rusk }\end{array}$ & $\begin{array}{l}\text { after } 1856 \\
\text { before } 1896\end{array}$ & $\begin{array}{l}\text { Rental owned by Michael } \\
\text { Ryan (BCDR S2:603) }\end{array}$ \\
\hline & 16 & Acequia section & $\begin{array}{l}115 \mathrm{ft} \text { long, } 1-3 \text { cour ses remained } \\
8-24 \text { inches bs }\end{array}$ & Table 4 & & & \\
\hline & 18 & $\begin{array}{l}\text { Wood-lined } \\
\text { privy }\end{array}$ & $\begin{array}{l}34 \text { inch diameter } \\
24-48 \text { inches bs }\end{array}$ & Table 3 & $\begin{array}{l}\text { NCB } 171, \text { Lot } 18 \\
238 \text { Rusk }\end{array}$ & $\begin{array}{c}\text { after } 1856 \\
\text { before } 1896\end{array}$ & $\begin{array}{l}\text { Rental owned by Michael } \\
\text { Ryan (BCDR S2:603) }\end{array}$ \\
\hline & 24 & Well & $\begin{array}{l}30 \text { inch diameter bells to } 52 \text { inches } \\
\text { at bottom } \\
15-18 \text { feet bs }\end{array}$ & no & $\begin{array}{l}\text { NCB } 171 \text {, Lot } 34 \\
\text { West side - Water St. }\end{array}$ & ca. 1867 & $\begin{array}{l}\text { Christian Speiser } \\
\text { (BCDR U1:385, U1:386) }\end{array}$ \\
\hline \multirow[b]{2}{*}{$41 \mathrm{~B} \times 1299$} & 7 & Artifact scatter & $\begin{array}{l}84 \text { inches long, width of trench } \\
47-63 \text { inches bs }\end{array}$ & no & $\begin{array}{l}\text { NCB 905, Lot } 29 \\
205 \text { Goliad }\end{array}$ & ca. 1866 & $\begin{array}{l}\text { Gustav Schmidt } \\
\text { (BCDR T2:400) }\end{array}$ \\
\hline & 12 & $\begin{array}{l}\text { Limestone- } \\
\text { rubble } \\
\text { foundation }\end{array}$ & $\begin{array}{l}1 \text { section, } 15 \mathrm{ft} \text { long } \\
24-58 \text { inches bs }\end{array}$ & no & $\begin{array}{l}\text { NCB 905, Lot } 29 \\
205 \text { Goliad }\end{array}$ & ca. 1866 & $\begin{array}{l}\text { Gustav Schmidt } \\
\text { (BCDR T 2:400) }\end{array}$ \\
\hline \multirow[t]{2}{*}{$41 B \times 1300$} & 8 & $\begin{array}{l}\text { Limestone } \\
\text { foundation }\end{array}$ & $\begin{array}{l}\text { NE corner, } 218 \text { inch wall section } \\
6-53 \text { inches bs }\end{array}$ & no & $\begin{array}{l}\text { NCB } 696, \text { Lot } 12 \\
316 \text { South St. }\end{array}$ & ca. 1892 & $\begin{array}{l}\text { George F. Icke } \\
\text { (BCDR 95:26) }\end{array}$ \\
\hline & 21 & Trash deposit & $\begin{array}{l}52 \text { inch diameter } \\
36-72 \text { inches bs }\end{array}$ & Table 5 & $\begin{array}{c}\text { NCB } 687, \text { Lot } 1,\left(\mathrm{~N}^{1 / 2}\right) \\
112 \text { Matagorda }\end{array}$ & $\begin{array}{c}\text { between } \\
1870-1897\end{array}$ & $\begin{array}{l}\text { Rental owned by H.B. Adams } \\
\text { and E. D. L. Wickes } \\
\text { (BCDR U2:59) }\end{array}$ \\
\hline
\end{tabular}






Figure 7. Feature locations. 
the late 1850 s and early 1860 s, diagnostic artifacts (described below) recovered from privies, wells, trash deposits, and acequia sections associated with these structures consistently date to between 1890-1910, the time period when privies and wells became trash receptacles as people in the area began to use the city water and sewer services (Brown and De La O 1997). Brief descriptions, illustrations, and lists of associated diagnostic artifacts for a representative sample of these post-1850 features is given below.

\section{Limestone Foundations}

\section{Feature 6 (41BX1296)}

Feature 6 is located on NCB 688, Lot 15, adjacent to west wall of the existing parking garage at the corner of Market and Bowie streets (Figure 7). The limestone block alignment that was eventually identified as the east wall of an "el"-shaped structure foundation was revealed in the northern section of the thermal-lines trench. The entire east wall and portions of the north and south wall of the foundation were present, and investigations indicate additional portions extend beneath the garage (Figure 8). The complete east wall measures $35 \mathrm{ft}$ in length; exposed portions of the north and south wall are $23 \mathrm{ft}$ and 20 $\mathrm{ft}$ long respectively. The three remaining courses of stones, measuring 56" from top to bottom, are held together by sandy, limebased mortar (see George, Appendix B, for discussion of architectural components). The builder's trench for the foundation extends only $1 / 4$ inch on either side of the stones and was excavated to the top of the red and $\tan$ marled caliche $B$ horizon.

Stones used in the foundation range from large, quarried blocks ( 24 inches thick x 36 inches long $x 24$ inches wide) to small rocks ( $<6$ inches in diameter) used to fill uneven places between the larger stones (Figure 9). In some cases, two or more narrow blocks have been placed together to make up the 24-inch overall width of the foundation. Limestone blocks show a variety of quarry marks (sawed, chiseled, drilled) and bored holes for lifting (Figure 9).

Neither the location of Feature 6 on the line dividing Lots 15 and 16 of NCB 688, nor the "el" shape of the uncovered portions of the structure, match structures shown along North Street on the 1896 Sanborn map (Figure 6) or Koch's 1873 Bird's Eye View of the City of San Antonio (Figure 5). However, the orientation of the structure indicates its is correctly placed for the street and lot layout

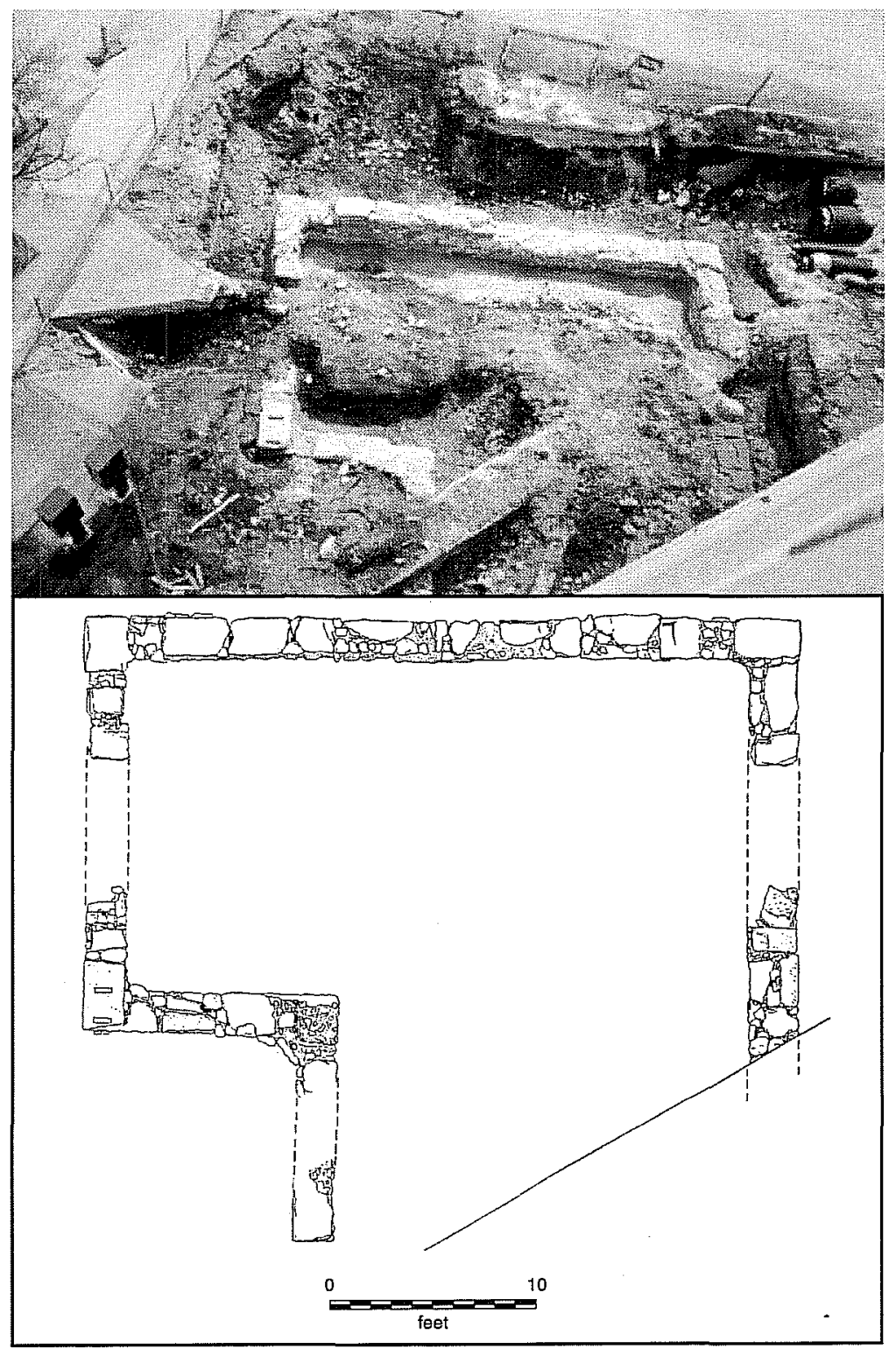

Figure 8. Photograph and plan view of Feature 6. 


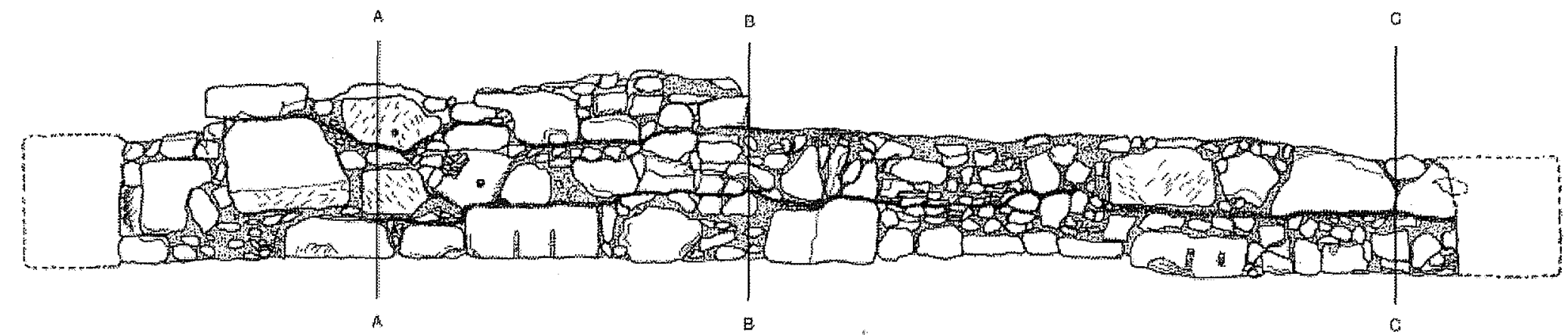

$\vec{\sigma}$

b

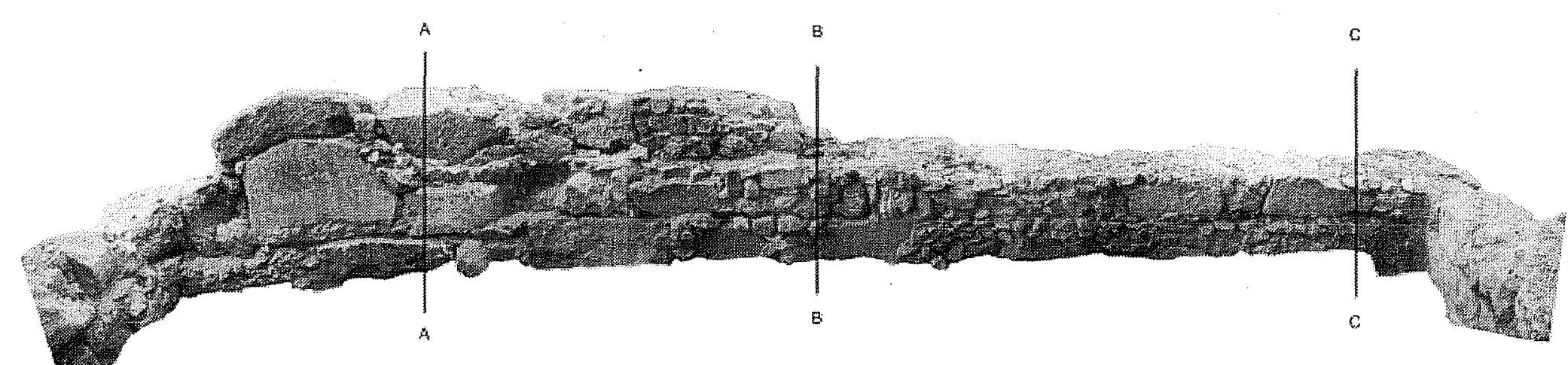

$c$

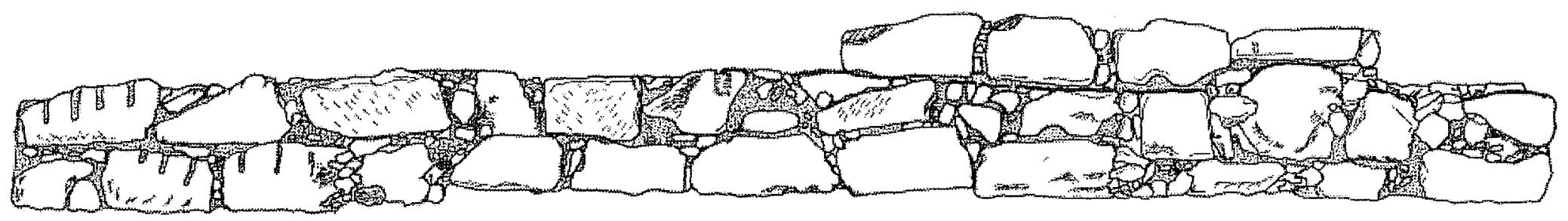

0 10

feet

Figure 9. Feature 6 profiles. a: scaled drawing of interior of east wall; b: panoramic photograph of interior of east wall; c: scaled drawing of exterior of east wall. 
associated with the Joseph Beck plat (Beckville). Beck sold Lot 15 to John Kraus in January 1855 (BCDR L2:185) and Lot 16 to Thomas McDermott in September 1854 (BCDR M2:263). Kraus sold Lot 15 less than eight months later to August Krandelt (BCDR N1:129) who in turn sold it to John Wilkins that same year (BCDR N1:296). Similarly, Lot 16 changed hands four times in five years before it was purchased by John Wilkins in 1859 (BCDR R1:369). Wilkins owned both lots until 1879 when lawsuits and other legal problems seem to have created a problem concerning the entire block. Nevertheless, it appears that this early structure on Lots 15 and 16 was built by John Wilkins, probably no earlier than 1859 when he acquired both Lots. The one diagnostic artifact recovered from the mortar between the foundation stones supports this construction date. It is an oval, brass belt plate engraved with the letters "U.S." (Figure 10). Belt buckles of this style and size were U.S. Army issue between 1856-1865 (Todd 1980:79-84). Non-diagnostic artifacts associated with Feature 6, also from within the mortar, include one animal bone fragment, one piece of undecorated ironstone, four window glass fragments, and six cut nails.

The entire east wall and portions of the northeast and southeast corners of the foundation were removed. However, the majority of the north and south walls as

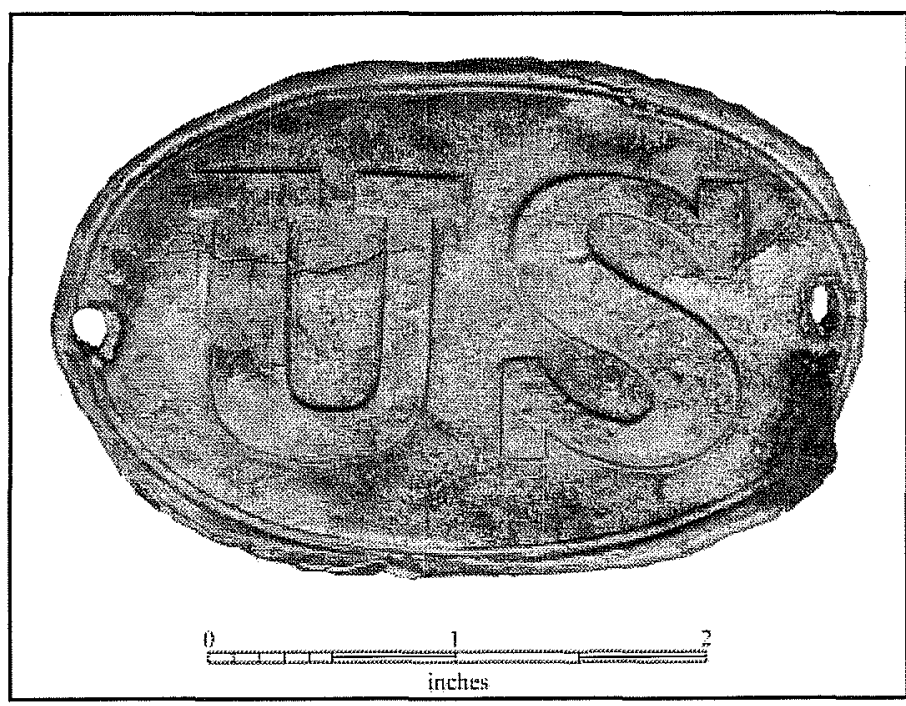

Figure 10. 1856-1865 U.S. Army belt buckle found in the mortar in Feature 6 foundation. well as an undetermined amount of the structure beneath the existing parking garage remain intact.

\section{Other Foundation Features}

As shown in Table 2, remnants of 10 structure foundations in addition to Feature 6 were uncovered during various phases of the project. The locations of these foundations could be easily associated with structures shown on the 1896 Sanborn map. These structures are known to be part of post-1850 Beckville or later building episodes. These foundations were constructed of cut limestone blocks 17-18 inches thick that are held together by a light tan, sand and lime mortar. The foundation remnants were uncovered at varying depths across the project area (Table 2). They consisted of 5-15 ft long sections, one to three courses in thickness that had each had been truncated below the historic living service by previous construction activities. Examples of the most complete of the foundation remnant features are shown in Figures 1113. No diagnostic artifacts were found in association with any of the foundation features; however, a small scatter of animal bones and non-diagnostic ceramics (Feature 7) were recovered approximately $40 \mathrm{ft}$ west of foundation Feature 12. Foundations within the building footprint were demolished but those along the thermal-lines trench remain intact.

\section{Privy Features}

Remnants of two brick-lined (Feature 1 and 13) and one wood-lined feature (Feature 18) were uncovered during the project (Figure 7). These features are believed to be privies or cisterns associated with the residences at 219 Water, 315 South, and 238 Rusk streets respectively (Table 2). Features 1 and 18 are briefly described below.

\section{Feature $1(41 B X 1298)$}

The bottom layer of a rectangular privy, designated Feature 1, was uncovered 38.5 inches below the surface in the thermal-lines trench 
Figure 11. Foundation Feature 9.
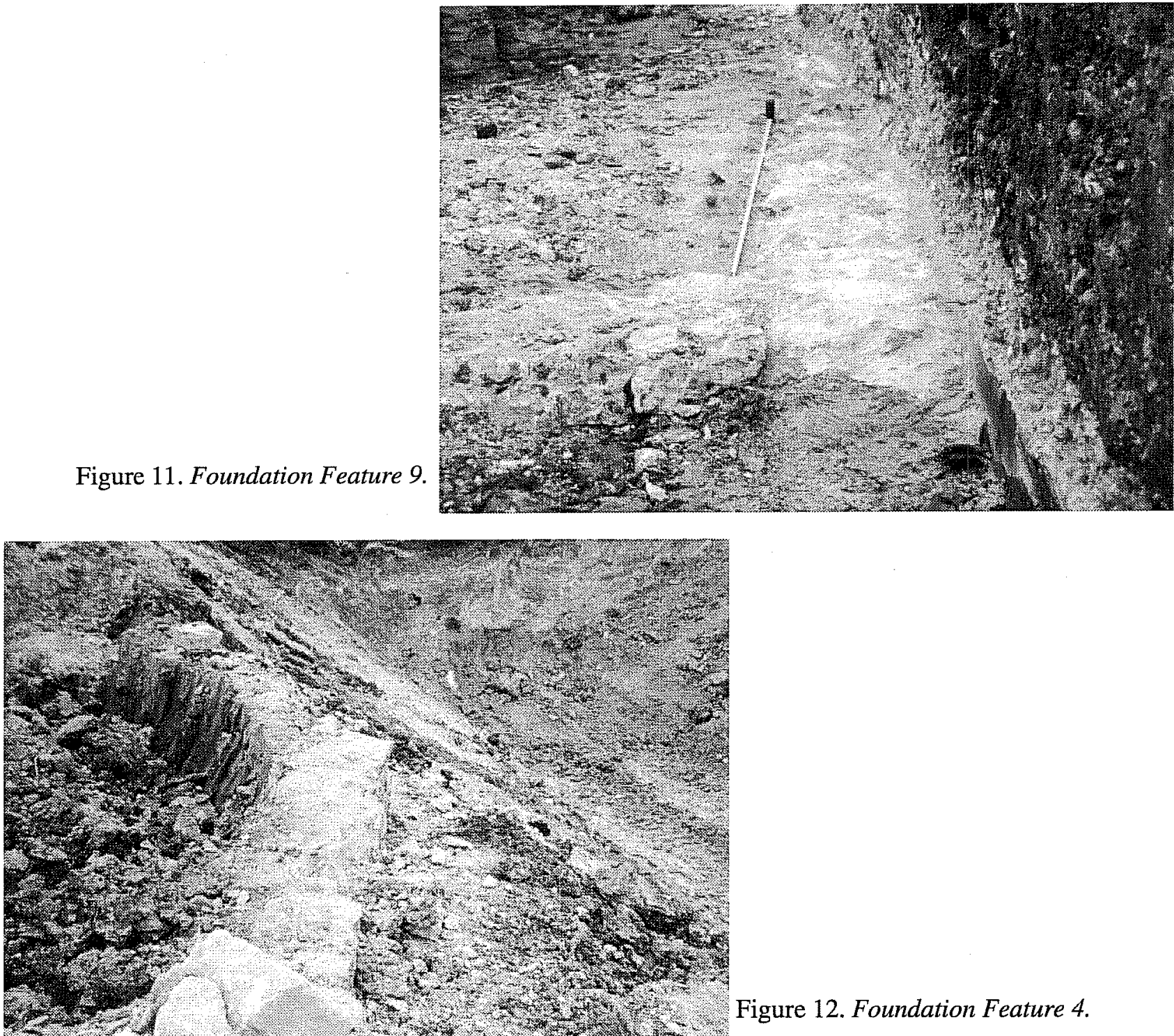

Figure 12. Foundation Feature 4.

Figure 13. Foundation Feature 8.

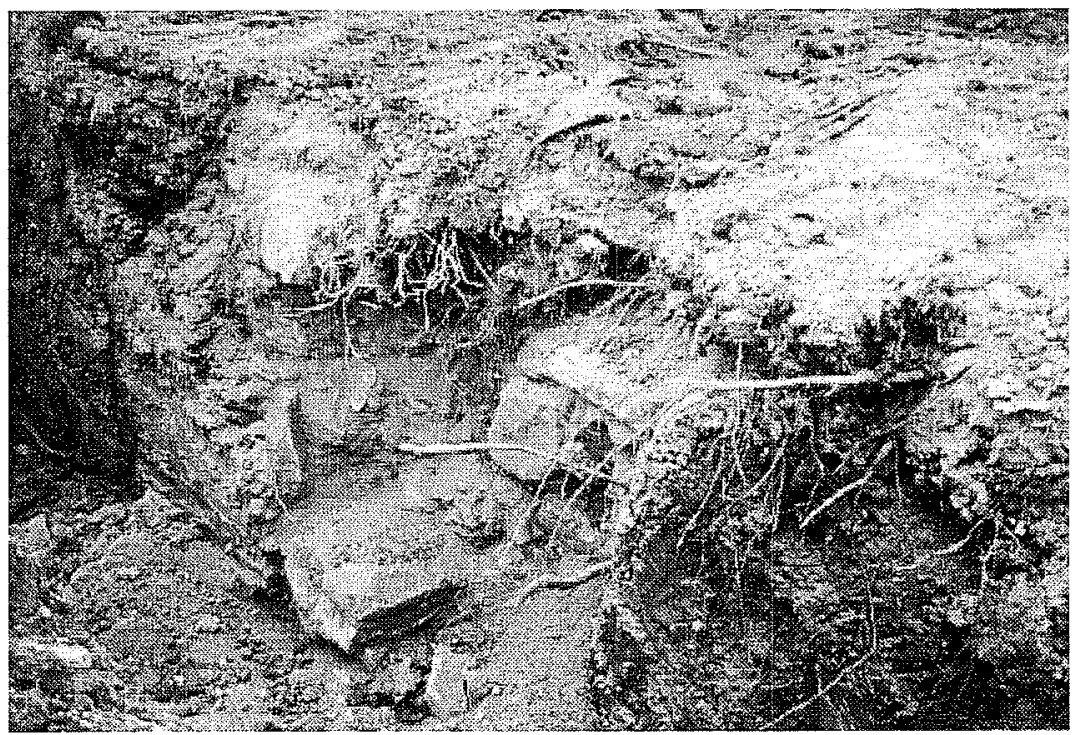


behind the Lila Cottrell Theater (Figure 7). It measured 36-x-47 inches and was constructed of 5-x-10 inch tan bricks held to together by a dark tan sandy mortar (Figure 14). Although the upper portion of the feature was removed by previous construction activities and replaced by modern construction base, numerous post1850 artifacts remained in the bottom layer (Table 3).

\section{Feature 18 (41BX1298)}

A wood-lined feature believed to be a privy was revealed at the western edge of the footprint excavation 48 inches beneath the slab for the existing convention center (Figure 15). This feature is lined with $2-x-4$ inch vertical wood slats and is slightly bowed outward in the center. It could possibly be a wooden barrel but no evidence of metal straps was present. The fill inside the feature is a mixture of dark ash and gravels with a few artifacts distributed evenly throughout (Table 3 ). It is clear in Figure 18 that the feature was truncated and covered with base during construction of the existing convention center.

\section{Well Features}

Two wells, Features 5 and 24, were present in the project area (Figure 7). Feature 5 was observed as an unlined deposit of black clay intruding into the natural gravels in the south face of thermal lines tunnel trench (Figure 16). The feature began approximately $2 \mathrm{ft}$ below the surface and continued to the bottom of the trench, which in this location was $14 \mathrm{ft}$ below the surface. Due to the location of this feature in the trench and the depth of the trench, complete measurements could not be obtained. Several buckets of fill from the feature produced only animal bones and unidentifiable rusted-metal fragments. Because of its size, depth, and location beneath the demolished arena, it is possible that this feature represents a hole drilled for a concrete arena support pier that was subsequently abandoned.

Table 3. Diagnostic Artifacts from Privy Features

\begin{tabular}{|c|c|c|c|c|}
\hline Feature & Artifact Type & Markings & Date & Reference \\
\hline \multirow[t]{6}{*}{1} & $\begin{array}{l}\text { glass pharmacy } \\
\text { measuring jigger }\end{array}$ & $\begin{array}{l}\text { Dowling \& Flood Druggist } \\
\text { San Antonio, Texas }\end{array}$ & $1881-1896$ & City Directory \\
\hline & whole bottle & $\begin{array}{l}\text { W. D'Albini } \\
\text { San Antonio, Texas }\end{array}$ & $1887-1893$ & City Directory \\
\hline & whole bottle & $\begin{array}{l}\text { F. Kalteyer \& Son Drug Store } \\
\text { Military Plaza } \\
\text { San Antonio, Texas }\end{array}$ & $1879-1891$ & City Directory \\
\hline & paneled bottle & $\begin{array}{l}\text { John G. Koch, Farmers Drug Store } \\
318 \text { E. Commerce, San Antonio }\end{array}$ & $1892-1894$ & City Directory \\
\hline & paneled bottle & $\begin{array}{l}\text { E. Reuss, City Drug Store } \\
108 \text { E. Commerce, San Antonio, Texas }\end{array}$ & $1892-1901+$ & City Directory \\
\hline & decorated whiteware & multi-colored decal & post 1850 & Durr enber ger (1965:21) \\
\hline \multirow[t]{5}{*}{13} & $\begin{array}{l}\text { brown transfer } \\
\text { decorated saucer }\end{array}$ & Charles Allerton \& Son, England & $1890+$ & Godden (1964:30) \\
\hline & $\begin{array}{l}\text { pink transfer } \\
\text { decorated saucer }\end{array}$ & Charles Allerton \& Son, England & $1890+$ & Godden (1964:30) \\
\hline & und. whiteware & Cockson \& Seddon & $1875-1877$ & Godden (1964:159) \\
\hline & und. whitew are & H. Burgess, Burslem & $1864-1892$ & Godden (1964:116) \\
\hline & und. whiteware & K. T. \& K. Granite & ca. 1890 & $\begin{array}{l}\text { Gates and Ormerod } \\
(1982: 119)\end{array}$ \\
\hline \multirow[t]{2}{*}{18} & und. whiteware & Stone China, E\&C Challinor, England & $1862-1891$ & Godden (1964:137) \\
\hline & stoneware & Albany-slip glaze & $1860-1900$ & Greer $(1981: 264)$ \\
\hline
\end{tabular}




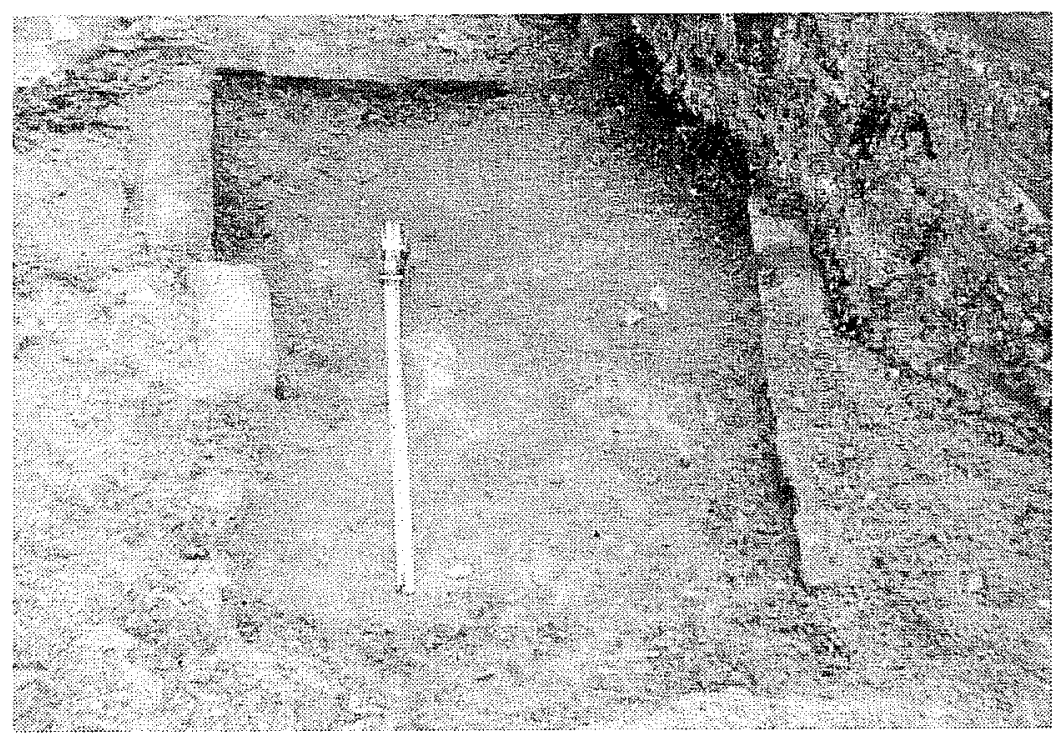

Figure 14. Brick-lined privy Feature 1.

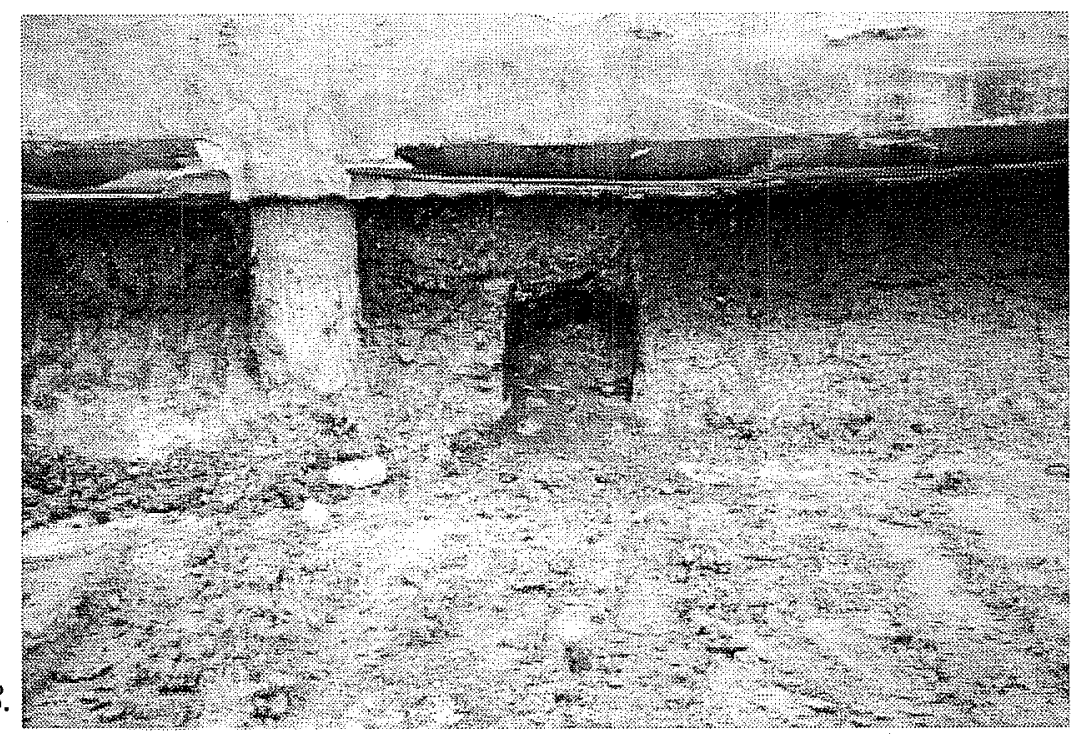

Figure 15. Wood-lined privy Feature 18.

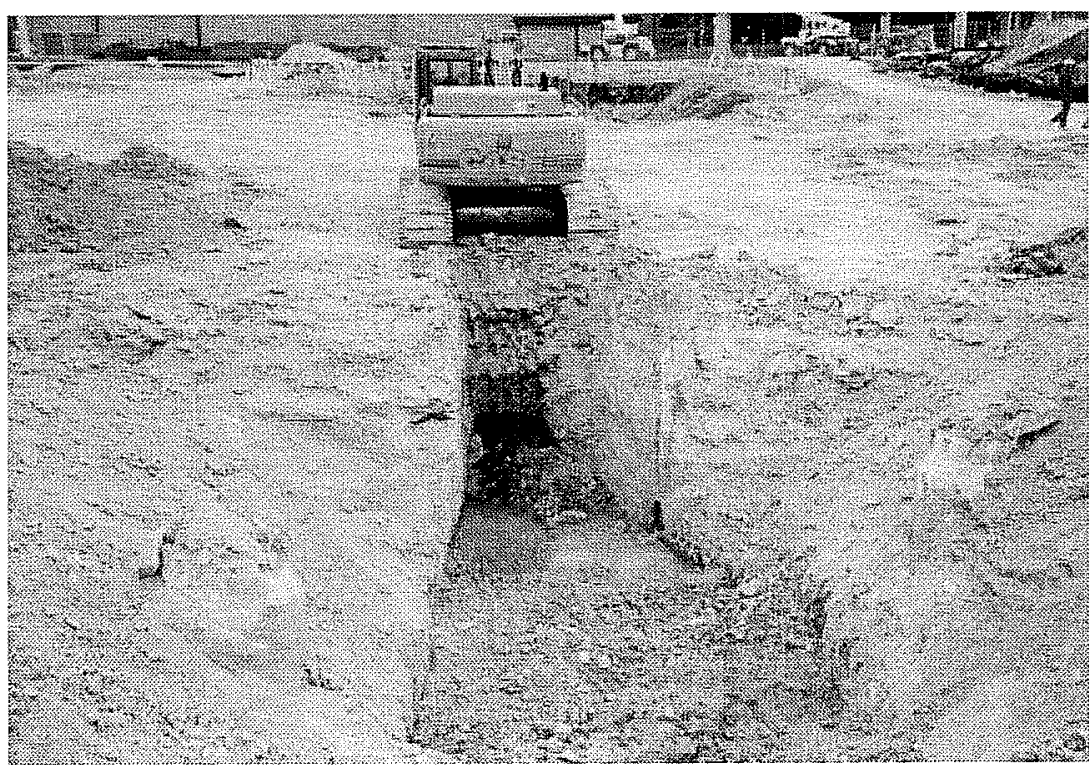

Figure 16. Well Feature 5. 


\section{Feature 24 (41BX1298)}

This rock-lined deposit of black clay was observed within the deeply excavated western section of the convention footprint (Figure 7). The top of the remaining portion of this circular feature was $15 \mathrm{ft}$ below the surface and measured 30 inches in diameter. At the bottom depth of $18 \mathrm{ft}$ below the surface, the feature belled out to a diameter of 52 inches. There is no way to estimate the extent of this feature that was removed during previous construction episodes. The feature was lined with small (3-6 inch) stones with no apparent mortar. Although numerous pieces of wellpreserved animal bone and leather items, including a boot sole and heel, a curie brush, and harness straps were observed, no temporally diagnostic artifacts were present.

\section{Acequia Sections}

Two sections of the west branch of the Alamo Acequia (Features 11 and 16) were encountered during this project (Table 2). Both sections were in locations documented on Koch's 1873 Bird's Eye View of the City of San Antonio (Figure 5) and the 1896 Sanborn map (Figure 6). The Alamo Acequia and its branches date from the Spanish-colonial period when these waterways served as irrigation ditches for the agricultural fields serving Mission Valero. They remained in use, serving the same purpose, until the close of the nineteenth century. Initially, the acequias were earthen ditches; the stone lining we find in the major acequia remnants today was added beginning in 1842 . Unfortunately, periodic cleaning of these canals, necessary to keep the water moving smoothly, has removed all but the late nineteenth and early twentieth-century artifacts deposited there shortly before the channels were closed. Numerous fragments of broken glass, undecorated whiteware, rusted metal, and animal bones were observed in the acequia deposits uncovered during this project. The few diagnostic pieces present, listed in Table 4, date to the turn of the century.

\section{Feature 11 (41BX1298)}

Feature 11 was uncovered during thermal-line trenching between the Institute of Mexican Culture and the South Banquet Hall of the existing convention center (Figure 7). This $20 \mathrm{ft}$ section of the acequia was revealed beneath $3 \mathrm{ft}$ of modern base in the eastern edge of the excavation. It consists of a sparse scatter of late nineteenth- and early twentieth-century artifacts in a 5-ft-thick black clay and gravel matrix. A clay pipe, resting on a two-inch-thick layer of caliche, runs along this deposit as if the pipe had been placed in the acequia ditch while it was still open (Figure 17). However, while the soil above the clay pipe shows evidence of the disturbance caused when the clay pipe was installed and covered, similar quantities of artifacts are present both above and below the pipe. Six pieces of uncut limestone measuring 12-24 inches in length were visible at the north end of the

Table 4. Diagnostic Artifacts from Acequia Features

\begin{tabular}{|c|l|l|c|l|}
\hline Feature & \multicolumn{1}{|c|}{ Artifact Type } & \multicolumn{1}{|c|}{ Markings } & \multicolumn{1}{c|}{ Date } & \multicolumn{1}{c|}{ Reference } \\
\hline \multirow{2}{*}{11} & stoneware & Albany-slip glaze & $1860-1900$ & Greer $(1981: 264)$ \\
\cline { 2 - 6 } & stoneware & Bristol glaze & 1884 & Greer $(1981: 210)$ \\
\hline \multirow{2}{*}{16} & und. whiteware & $\begin{array}{l}\text { Royal Patent Ironstone } \\
\text { Wood \& Son, England }\end{array}$ & $1891-1907$ & Godden (1964:689) \\
\cline { 2 - 6 } & und. whiteware & $\begin{array}{l}\text { J. G. Meakin } \\
\text { Hanley, England }\end{array}$ & $1890+$ & Godden (1964:427) \\
\cline { 2 - 6 } & stoneware & Albany-slip glaze & $1860-1900$ & Greer (1981:264) \\
\cline { 2 - 6 } & und. whiteware & Burford Bros. & $1881-1904$ & Gates and Ormerod (1982:26) \\
\cline { 2 - 6 } & wire nails & & post 1879 & Fontana (1965) \\
\hline
\end{tabular}


excavation. These stones possibly represent a disturbed section of the acequia's rock-lined eastern wall; no stones representing the west wall were present. Portions of this acequia deposits were destroyed during the current project, but there is a good possibility that additional portions, including a Spanish-colonial period control gate, remain to the south beneath the Institute of Mexican Culture.

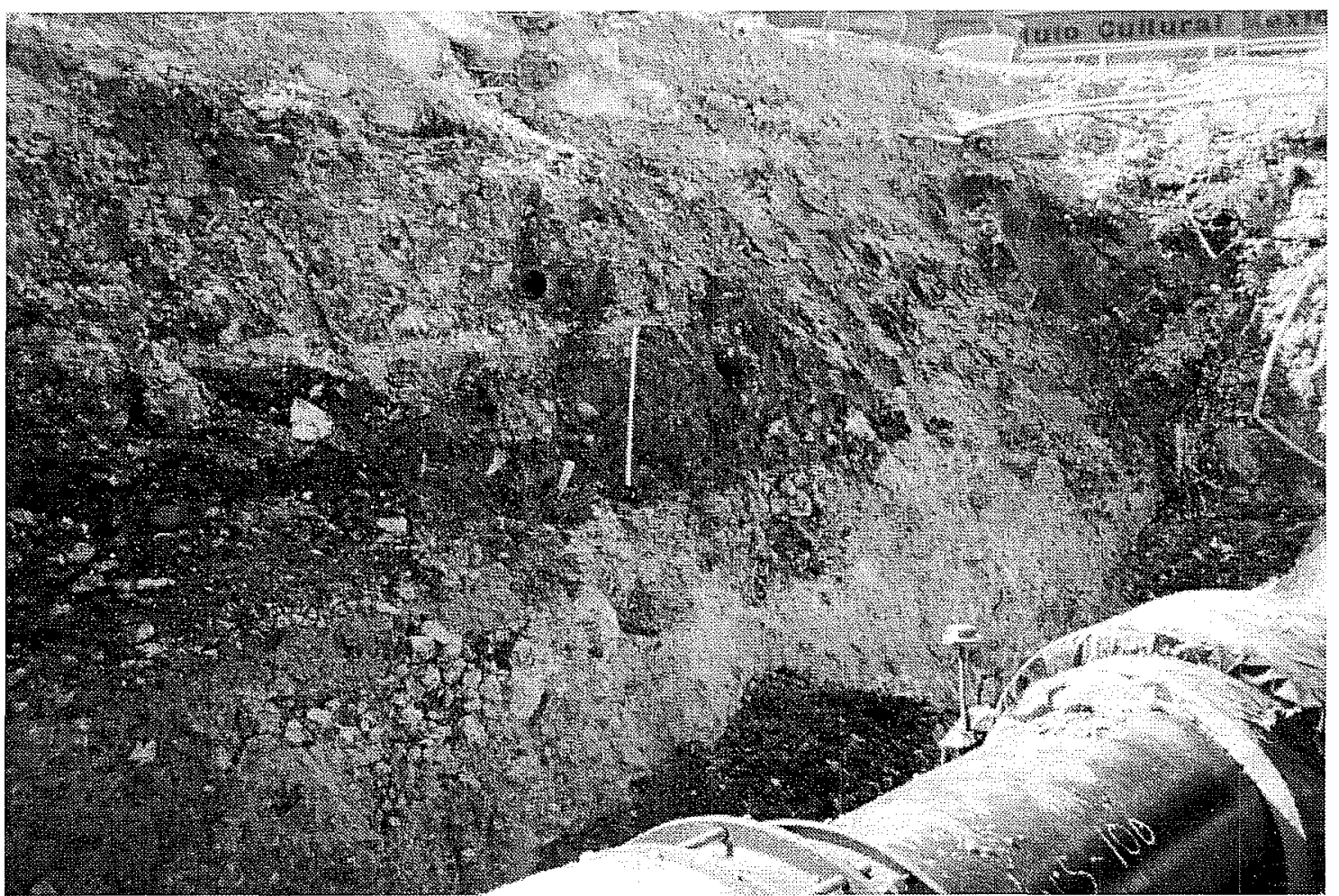

Figure 17. Acequia Feature 11. Note relationship of the clay pipe (left of measuring tape above) to the acequia deposit in the skematic profile below.

Figure 18. Skematic profile of east wall Acequia Feature 11.

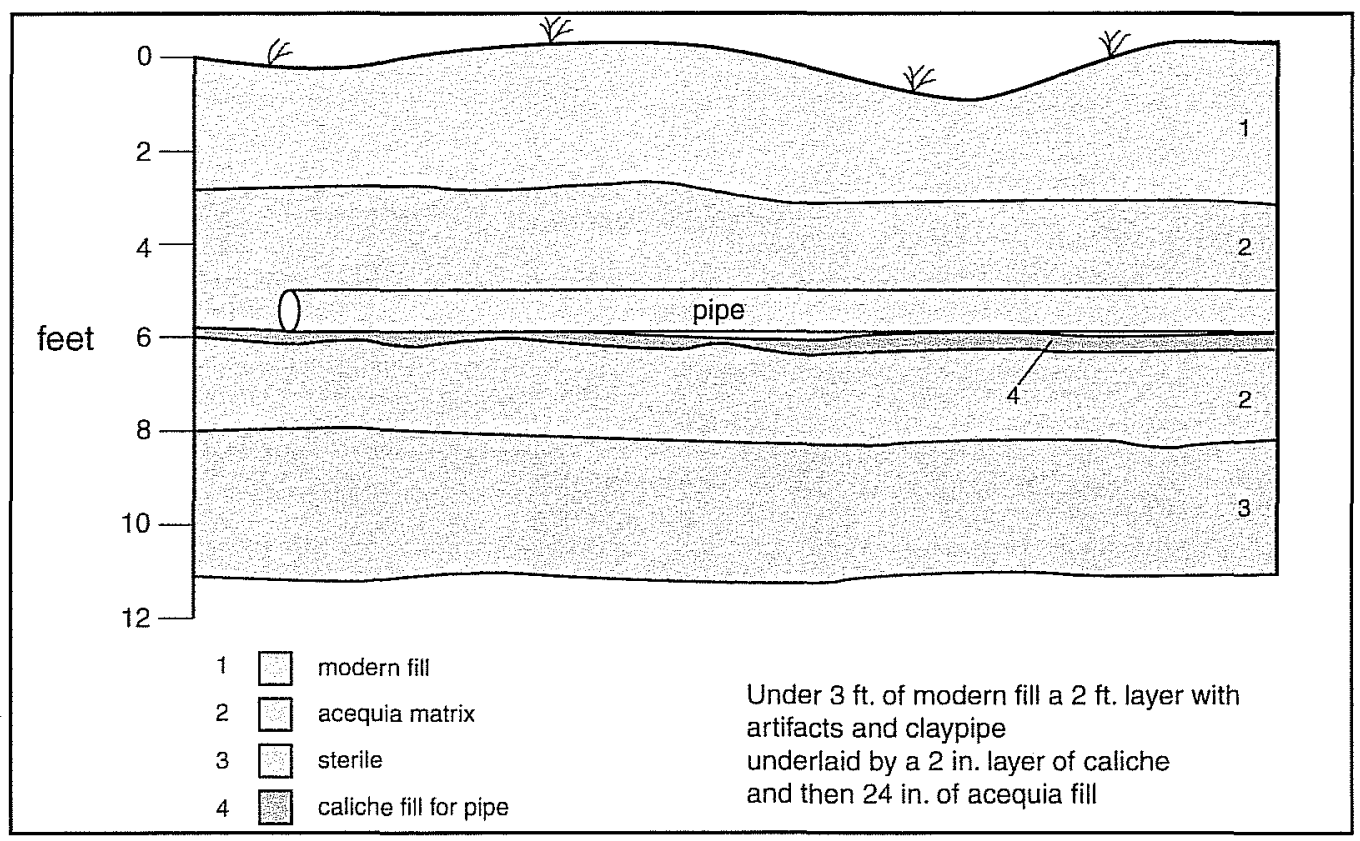




\section{Feature $16(41 B X 1298)$}

This $115 \mathrm{ft}$ section of the western branch of the Alamo Acequia was uncovered during excavation of the expansion footprint beneath the demolished arena (Figure 7). One to two courses of cut limestone blocks representing the east wall were present (Figures 19 and 20). Investigations along this expanse revealed that the inside of the acequia had been virtually destroyed by support piers installed during construction of the arena. Two small pockets of post- 1880 artifacts were present within this disturbed context (Table 4).

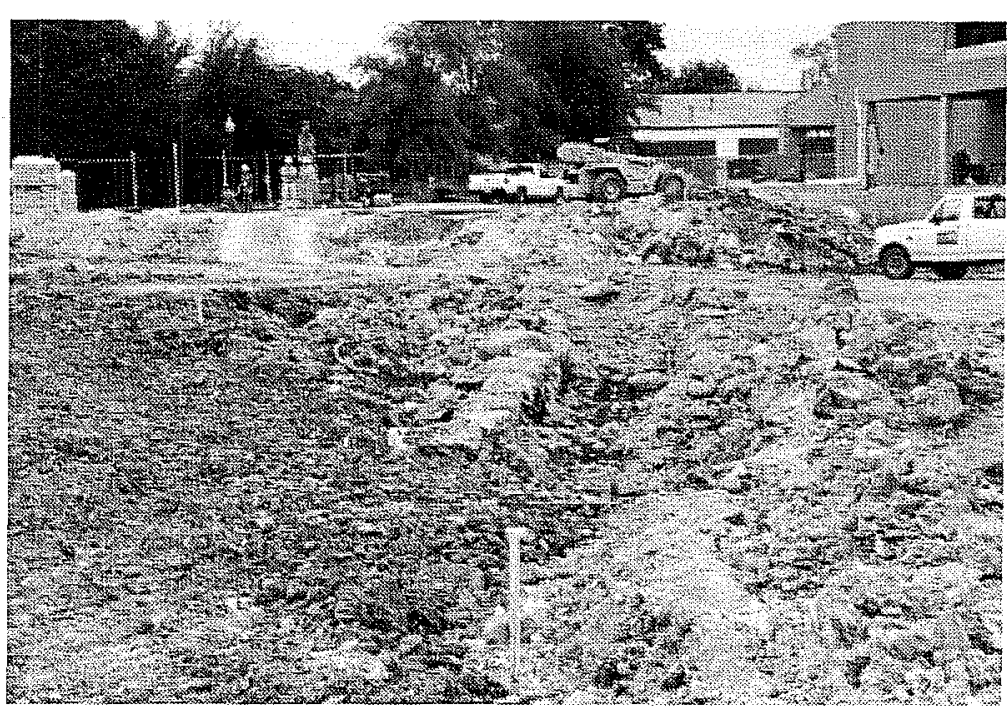

Figure 19. Acequia Feature 16. Looking south.

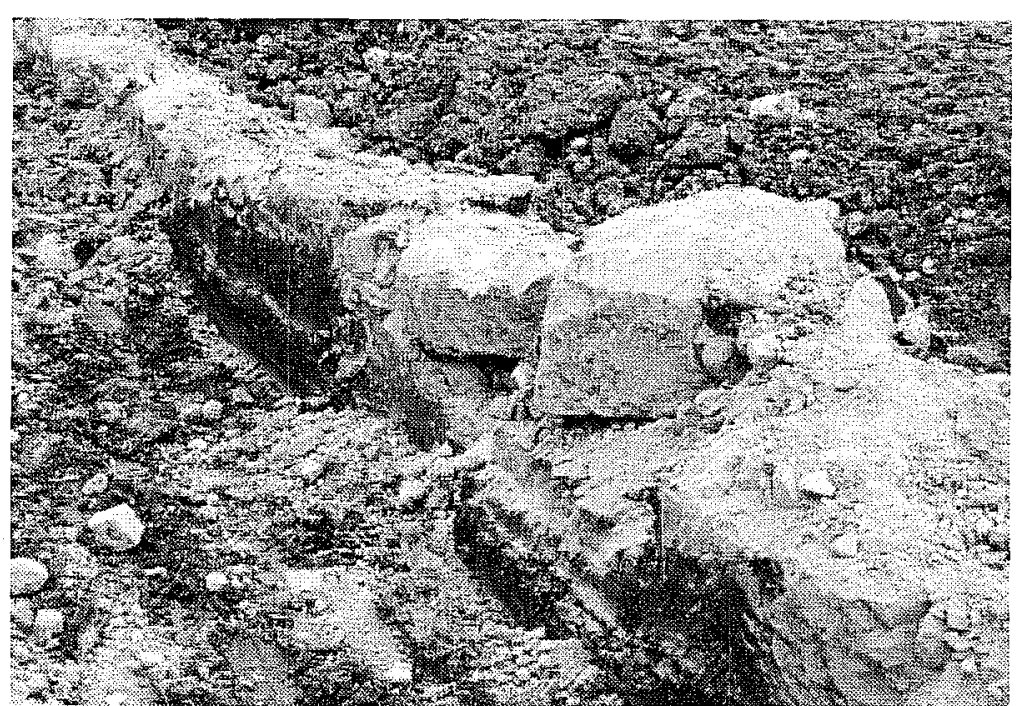

Figure 20. Stones forming east wall of Feature 16.

\section{Artifact Clusters}

Two artifacts scatters (Features 2 and 7) and four artifact clusters that appear to be the remains of historic trash pits (Features 14, 21,23 , and 25) were identified during the project (Table 2). Features 2 and 7 were amorphous scatters revealed in the thermallines trenches (Figure 7) and appear to be the result of displacement during previous construction activities. Features 14, 21, 23, and 25 , within the expansion footprint, were clusters of artifacts in unlined ashy deposits that probably represent Historic-period trash pits (Figure 10). Again, the diagnostics from these features date to the late nineteenth century (Table 5).

Table 5. Diagnostic Artifacts from Cluster Deposits

\begin{tabular}{|c|l|l|c|l|}
\hline Feature & \multicolumn{1}{|c|}{ Artifact Type } & \multicolumn{1}{|c|}{ Markings } & \multicolumn{1}{c|}{ Date } & \multicolumn{1}{c|}{ Reference } \\
\hline 2 & und. whiteware & Wheeling Pottery & 1879 & Kovel and Kovel (1971:170) \\
\hline 14 & pharmacy bottle & $\begin{array}{l}\text { Dowling \& Flood Apothecaries } \\
\text { San Antonio }\end{array}$ & $1881-1896$ & City Directories \\
\hline 21 & und. whiteware saucer & $\begin{array}{l}\text { Stone China } \\
\text { J. W. \& Son }\end{array}$ & $1898-1926$ & Godden (1964:675) \\
\hline 23 & und. whiteware & $\begin{array}{l}\text { Th... Furnival \& Son, } \\
\text { Trade Mark, England }\end{array}$ & $1871-1890$ & Godden (1964:263) \\
\hline 25 & stoneware crock & Albany glaze & $1860-1890$ & Greer (1981) \\
\hline
\end{tabular}




\section{In-depth Discussion on Identified Features}

\section{BX1296}

Along with Feature 6, the foundation discussed earlier in the report, Features $17,22,23$, and 25 were also located within NCB 688, site 41BX1296.

\section{Feature 17}

This limestone foundation located at the rear of the adobe structure on Lot 7, 131 Centre Street, was an auxiliary structure that was probably constructed sometime prior to the death of Jacob Witzel, ca. 1897 (Bexar County Probate Records [BCPR] \# 2340). There is no evidence that Witzel or his family ever occupied this property and it appears that the structure was constructed as a rental property. From as early as 1903 until 1928 the property was rented to George Eckenroth, who was employed at Alamo Iron Works (City Directories 1903-1928). At that time Eckenroth purchased the property from the estate of Clemens Witzel, a minor, through his guardian (BCDR 834:616). No artifacts were found in association with this structure.

\section{Feature 22}

This limestone foundation remnant was associated with a small frame dwelling located in the rear of the homes facing on Centre Street. The western portion of this property (Lot 3) was initially purchased by Zacharias Golloff from Joseph Beck in 1855 (BCDR G2:309). Three years later, Golloff aquired the adjacent lot (Lot 4) from Mathias and Mary Hoffmeister (BCDR R2:368). The two homes facing on Centre Street were probably constructed during this early period, the adobe structure on Lot 3 as a residence and the frame structure on Lot 4 as a rental house. The homes at the rear were constructed at a later date, possibly after 1902 when William Golloff sold the lots to Emil and Helene LaBroche (BCDR 203:304). LaBroche was a contractor residing at that time at 117 Santos Street (City Directory 1899-1900). No artifacts were found with this structure.

\section{Features 23 and 25}

These small trash deposits are most probably associated with the dwelling at $3161 / 2$ North Alley. The lot was purchased by Henry Seminger in September 1865 (BCDR T1:483). A large frame house was constructed fronting on North Street sometime after the purchase (Sanborn maps 1896, 1904). Henry deeded the property to his wife Winifred in 1881 and it is possible that the rental home in the rear was constructed near this date (BCDR 12:238). Upon his death in June 1891, all the property was inherited by his widow (BCPR \# 1858). She continued to reside at the family residence with her five children. In 1909 the home to the rear was occupied by Fannie Jefferson, a black renter (City Directory 1909). At the time of Winifrid's death in 1927, the estate sold the property to Victor A. Vida and his wife (BCDR 977:111). Because of their long manufacture and use dates, the artifacts from these two features could not be associated with a specific occupation period.

\section{BX1297}

\section{Feature 4}

This limestone foundation was a portion of the Ferdinand Langer home, constructed ca. 1874 (BCDR 1:343) at 102 Centre Street. Langer operated Stall 8 of the Alamo Meat Market, located in the middle of Alamo Plaza. This meat market, the oldest public market on the east side of the river, served the area from 1859 until near the turn of the century (City Directory 1879-80; Steinfeldt 1978 pp. 79-80). The home was also occupied, at various times, by his sons, Ferdinand, Jr., and John, also butchers working with their father; and Frank, a fireman for the Southern Pacific Railroad, and later a letter carrier for the Postal Department (City Directories 1899-1902). By 1903 the home had become rental property and was occupied by L. Matthews, a peddler, and by 1905 by Dr. L. L. Whittaker (City Directories 1903-1906). By 1907, James Langer, an agent for Metropolitan Life Insurance Company, had inherited the home and was in residence (City Directory 1907-08). In 1909 the house was again rental property and was occupied by Charles Hagen and his wife, Lizzie. Hagen was also 
an insurance agent (City Directory 1908). In 1928, the heirs sold the property to J. N. Crasilneck and his wife, Bertha, who sold the property the following year to Mary Emilie Eichlitz and her husband Fred (BCDR $1021: 481 ; 1107: 592)$. No artifacts were found in association with this structure.

\section{Features 5, 13, and 14}

This well, privy, and trash pit were located on the property occupied by 316 Center Alley. The property was a gift from Frank Wieczarek to Mary Haller and her husband, George, in 1868 (BCDR U1:162). George Haller and Mary Whitchell were married June 23, 1865 (Bexar County Vital Statistics Office, Marriage Record Book D2:461). George died sometime prior to 1879 when Marie became a laundress at the Menger Hotel on Alamo Plaza (City Directory 1879-80). In April 1887, Marie married Max Schmitt (BCDR 53:591). By 1913, the property had been transferred to George J. Haller. Haller, probably a son by Marie's first marriage, owned and operated a saloon in the neighborhood at 314 Water Street (City Directories 1892-1902). In 1913 George and Hulda Haller established the residence as their homestead (BCDR 413:310). By 1922, George was deceased and Hulda partitioned the property and sold the portion facing on South Street, and containing the privy, to Julia H. Bass (BCDR 675:295). The property was transferred to Hulda's heirs in 1928 (BCPR 1025:358-60; 1232:190). The yellow brick used to construct this privy feature did not become readily available or inexpensive in San Antonio until the railroad came in 1877 . This, along with the post- 1890 date for most of the diagnostics in the privy (Table 3) and the pharmacy bottle from cultural material was deposited while Marie Haller lived at 316 Center Alley.

\section{Features 9 and 19}

The limestone foundation designated Feature 9 was for the structure located at 126 Centre Street, later 124 Wyoming, while Feature 19 is a smaller structure at the back of the property. The property was purchased ed from H. Beck by Frederich Achleberg in July 1859 , who conveyed it to Magdaline Rudeman in February of 1865 (BCDR H2:151; T2:684). Magdaline married
Joseph Kohr in July of 1879 , and in August of the following year they took out a mechanic's lien for construction of their home on the property (Bexar County Vital Statistics Office, Marriage Record Book G:13; BCDR ML A:182). They occupied the home until 1902 when they sold the property to Theresa Janszen, the widow of F. Janszen (BCDR 210:302; City Directory 1909). In 1910 the structure was occupied by Theresa and her family; Johanna, who was employed by the Southwestern Telephone Company; Mitchell and Willie, messengers of the Postal Telegraph and Cable Company; and H. and Ernestine Erler, a stonemason and his wife who possibly occupied the smaller structure (City Directory 1910). In 1914 Theresa sold the property to Mrs. Emilie I. Tips (BCDR 452:314). This structure was still standing until destroyed for the construction of HemisFair in 1968. No artifacts were encountered in association with either of these structures.

\section{BX1298}

\section{Features 1 and 2}

This brick-lined privy and artifact scatter were probably associated with the residence located at 219 Water Street, constructed for Frederick E. Grothaus in 1877 (BCDR 8:357). Grothaus was a bookkeeper for the firm of Hugo and Schmeltzer, wholesale grocers and liquor store located at the site of the Alamo (City Directories 1879-1897). In June 1897, F. E. Grothaus and his wife, Luna, sold the property to N. N. Vindquest for $\$ 2.500$ (BCDR 141:624). Vindquest, his wife Caroline, and their two children occupied the home until after 1910 (City Directories 1898-1910). The diagnostic artifacts from these two features date between 1879-1901+, suggesting that they were deposited while the Grothaus family occupied the property. It is possible that by 1897 , when the Vindquest family bought the property, indoor plumbing had already replaced the need for the outdoor, yellow-brick privy.

\section{Feature 15}

Feature 15, the structure at 238 Rusk, and its associated wood privy (Feature 18), were built sometime between 
1856-1896 as rental properties by Michael Ryan but the long time span of the artifacts from this privy (1860-1900) precludes more detailed information on the occupants or the time period involved.

\section{Features 11 and 16}

The diagnostics from the two sections of the acequia (Features 11 and 16) group in the last quarter of the nineteenth century as expected since this branch of the Alamo Acequia remained in use until ca. 1910.

\section{BX1299}

\section{Features 7 and 12}

The artifact scatter and limestone foundation comprising 41BX1299 were at the site of the structure later designated 205 Goliad. Constructed ca. 1866, this caliche block building was on Goliad Road at the western crossing of the Alamo Acequia and served as a store and residence for Gustav Schmidt (BCDR T2:400). From this building Schmidt sold "groceries and provisions" assisted by his son, Albert, who served as his clerk and later as manager (City Directories 1879-80, 1887-88). In 1891 the property was seized by the Bexar County Sheriff for non-payment of taxes and sold to Paul Wagner at public auction. The heirs, Fredericka, Gustav, and Albert Schmidt protested the action and regained the property the same year (BCDR 99:613; District Court Records 1172, July 2). Albert Schmidt sold the property to N. M. Washer in April 1901 (BCDR 193:481). The structure was razed shortly thereafter (Sanborn map 1904, Volume 2). Although the artifacts from the scatter association with this structure were not diagnostic, the decorated whitewares and animal bone could have been the product of business conducted at the Schmidt store.

\section{BX1300}

\section{Feature 8}

This limestone foundation was for the structure located at 316 South St., constructed ca. 1882, by or for
Frederick and Anna Icke (BCDR 24:151). Fredrick, a painter, was deceased by 1899 and the homestead was occupied by his widow, Anna, and his sons Fredrick Jr., Martin, and George. The widow of Conrad Icke also lived with them at the residence (City Directories 1897-1900). George and his brother, William Icke, were owners and proprietors of George Icke and Brother Grocery and Dry Goods store at 501 East Commerce (City Directory 1897-98). Anna continued to reside at the homestead until her death in 1920 when the property passed to her heirs (BCDR 602:588). One of the heirs, Mrs. Anna Erher, sold the property to Herman Kircher at that time (BCDR 602: 586). No artifacts were found in association with this feature.

\section{Conclusion and Comments}

An unexpected amount of intact, subsurface historic deposits were present within the project area despite the massive amount of disturbance in this area created during previous activities associated with construction of HemisFair Park in the 1960s and the subsequent construction of the existing arena, convention center, and parking garage. These deposits, however, all date to the late nineteenth- and early twentieth-century occupations of the area. No pre-1850 deposits were impacted by excavations for the Bowie Street realignment, thermal-lines installations, or footprint excavations during the Convention Center Expansion project.

\section{Comments}

As a result of this project, some observations are possible that may be of assistance in designing future scopes of work for metropolitan projects of this type.

1. As just discussed, there was a considerable amount of archaeology remaining in the project area after the construction of HemisFair Park and its related facilities. Historic features were even present beneath larger structures like the arena, the parking garage, and the existing convention center building. In this case, the archaeological remnants represented a downtown neighborhood that did not develop until after the target date of 1850 , so no significant cultural 
resources were impacted. However, our findings during this project should serve as a reminder that the presence of previous construction activities in an area can not be used to definitely rule out the possibility of significant archaeological deposits.

2. The significance of the pre-1850 target date established for this project is actually difficult to isolate in the field. While a group of temporal diagnostics exist for the Spanish-colonial period in the form of distinct tools and ceramic types and the post-1870s have easily identified time markers, a similar suite from the first half of the nineteenth century has yet to be conclusively identified in this region's archaeological record. Compounding this difficulty is the fact that archival records from this period are sparse and census data does not exist until after 1877 . Until more early to mid-nineteenth-century sites are discovered and documented, identification of this period under monitoring restraints is an unrealistic goal.

3. Having noted that identifying deposits dating between $1820-1850$ during monitoring projects is almost impossible, it becomes necessary to add that monitoring of this large-scale construction project was a successful means of insuring that prehistoric and early historic period deposits were not destroyed. During this project, easily identifiable post-1870s artifacts were present in all the assemblages and, with the exception of Feature 6, foundation locations were acurately represented and recognizable on the historic maps.

4. It also bears noting that, with the exception of the serendipitous loss of the belt buckle during construction of Feature 6, no artifacts were found in direct association with structure foundations. The majority of the artifacts that were found were in privies and wells and all date to the time period when these features became trash receptacles as residents began to use the city water and sewer services. Evidence of earlier occupations that may have been in these features was systematically removed during citymandated privy cleanings. 


\section{References Cited}

ATC Associates

1996 Geotechnical Exploration: Henry B. Gonzalez Convention Center Expansion, HemisFair Park, San Antonio, Texas. Report No. 50-07-96-00009, Volume IG. Manuscript on file at the Center for Archaeological Research, The University of Texas at San Antonio.

Brown, M., and N. De La O

1997 Beneath the Crescent Moon: A Contextual and Architectural Analysis of Privies from the Alamodome Area. In Archaeology at the Alamodome: Investigations of a San Antonio Neighborhood in Transition, Volume III: Artifacts and Special Studies, edited by A. A. Fox, M. Renner, and R. J. Hard, pp. 256272. Archaeological Survey Report, No. 238. Center for Archaeological Research, The University of Texas at San Antonio.

Bousman, C. B., A. A. Fox, K. J. Gross, and I. W. Cox

1995 Historical Archaeology in Downtown San Antonio, Texas: An Evaluation of Properties at the Proposed VIA Downtown Park and Ride Facility. Archaeological Survey Report, No. 240, Center for Archaeological Research, The University of Texas at San Antonio.

Campbell, T. N.

1975 The Payaya Indians of Southern Texas. Special Publications No. 1. Southern Texas Archaeological Association, San Antonio.

Campbell, T. N., and T. J. Campbell

1985 Indian Groups Associated with Spanish Missions of the San Antonio Missions National Historical Park. Special Report, No. 16. Center for Archaeological Research, The University of Texas at San Antonio.

Chabot, F. C.

1937 With the Makers of San Antonio. Artes Graficas, San Antonio.

Cox, I. W., and A. A. Fox

1983 Literature and Archival Study for the Development of HemisFair Park, San Antonio, Texas. Manuscript on file. Center for Archaeological Research, The University of Texas at San Antonio.

de Paredes, M. S.

1727 Vista de las Misiones del Rio Grande del Norte pr Fr. Miguel Sevillano de Paredes en 15 de Octobre. Archivo General de Mexico: Historia, Volume 29. Barker History Center, The University of Texas at Austin.

Durrenberger, E. P.

1965 Anderson's Mill (41TV130): A Historical Site in Travis County, Texas. Bulletin of the Texas Archeological Society 36:1-70.

Fontana, B. L.

1965 The Tail of the Nail: On the Ethnological Interpretation of Artifacts. The Florida Anthrolopologist XVIII(3) 2:85-92. 
Fox, A. A., M. Renner, and R. J. Hard (editors)

1997 Archaeology at the Alamodome: Investigations of a San Antonio Neighborhood in Transition, Volume I: Historical, Architectural, and Oral History. Archaeological Survey Report, No. 236. Center for Archaeological Research, The University of Texas at San Antonio.

Gates, W. C., Jr., and D. E. Ormerod

1982 The East Liverpool Pottery District: Identification of Manufactures and Marks. Historical Archaeology 16:1-358.

Godden, G. A.

1964 Encyclopedia of British Pottery and Porcelain Marks. Bonanza Books, New York.

Greer, G. H.

1981 American Stonewares, The Art and Craft of Utilitarian Potters. Schiffer Publishing, Exton, Pennsylvania.

Habig, M.A.

1977 The Alamo Mission, San Antonio de Valero 1718-1793. Franciscan Herald Press, Chicago.

Hester, T. R.

1978 Early Human Occupations in South Central and Southwestern Texas: Preliminary Papers on the Baker Cave and St. Mary's Hall Sites. Non-serial Publication 2. Center for Archaeological Research, The University of Texas at San Antonio.

Hoffmann, F. L. (translator)

1938 The Mesquía Diary of the Alarcón Expedition into Texas, 1718. Southwestern Historical Quarterly, 41:312-323.

Johnson, E. D., I. Waynne Cox, and C. B. Bousman

1997 HemisFair Park, San Antonio, Texas: An Archival Study for the Convention Center Expansion. Archaeological Survey Report, No. 249. Center for Archaeological Research, The University of Texas at San Antonio.

Johnson, E. D., and I. Waynne Cox

1995 An Archival and Archaeological Study for the Relocation of Three Historic Homes in HemisFair Park, San Antonio, Texas. Archaeological Survey Report, No. 241. Center for Archaeological Research, The University of Texas at San Antonio.

Kovel, R. M. and T. H. Kovel

1971 Dictionary of Marks, Pottery and Porcelain. Crown, New York.

Lukowski, P. D.

1988 Archaeological Investigations at 41BX1, Bexar County, Texas. Archaeological Survey Report, No. 135. Center for Archaeological Research, The University of Texas at San Antonio.

Miller, G. L.

1991 A Revised Set of CC Index Values for Classification and Economic Scaling of English Ceramics from 1787 to 1880 . Historical Archeology, 25(1):1-25. 
Steinbomer, R. A.

1983 Brickmaking in Texas. Texas Historical Commission Special Report (Rough Draft), Appendix: South Texas. Austin.

Steinfeldt, C.

1978 San Antonio Was: Seen Through a Magic Latern. San Antonio Museum Association, San Antonio.

Taylor, F. B., R. B. Hailey, and D. L. Richmond

1991 Soil Survey of Bexar County, Texas. Soil Conservation Service, U.S. Department of Agriculture, Washington, D.C.

Tennis, C. L.

1994 Evaluation of Archaeological Material from the Little Church of La Villita Property, San Antonio, Texas. Archaeological Survey Report, No. 228. Center for Archaeological Research, The University of Texas at San Antonio.

1997 Ceramic Patterns and Variations. In Archaeology at the Alamodome: Investigations of a San Antonio Neighborhood in Transition, Volume III: Artifacts and Special Studies, edited by A. A. Fox, M. Renner, and R. J. Hard, pp. 1-37. Archaeological Survey Report, No. 238. Center for Archaeological Research, The University of Texas at San Antonio.

Todd, F. P.

1980 American Military Equipage: 1851-1872. Charles Scribner's Sons, New York.

Williams, P

1978 Staffordshire Romatic Transfer Patterns: Cups, Plates, and Victorian China. Fountain House East, Jefferson, Kentucky. 
Appendix A. List of Local Druggists

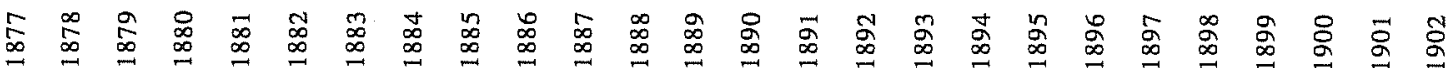

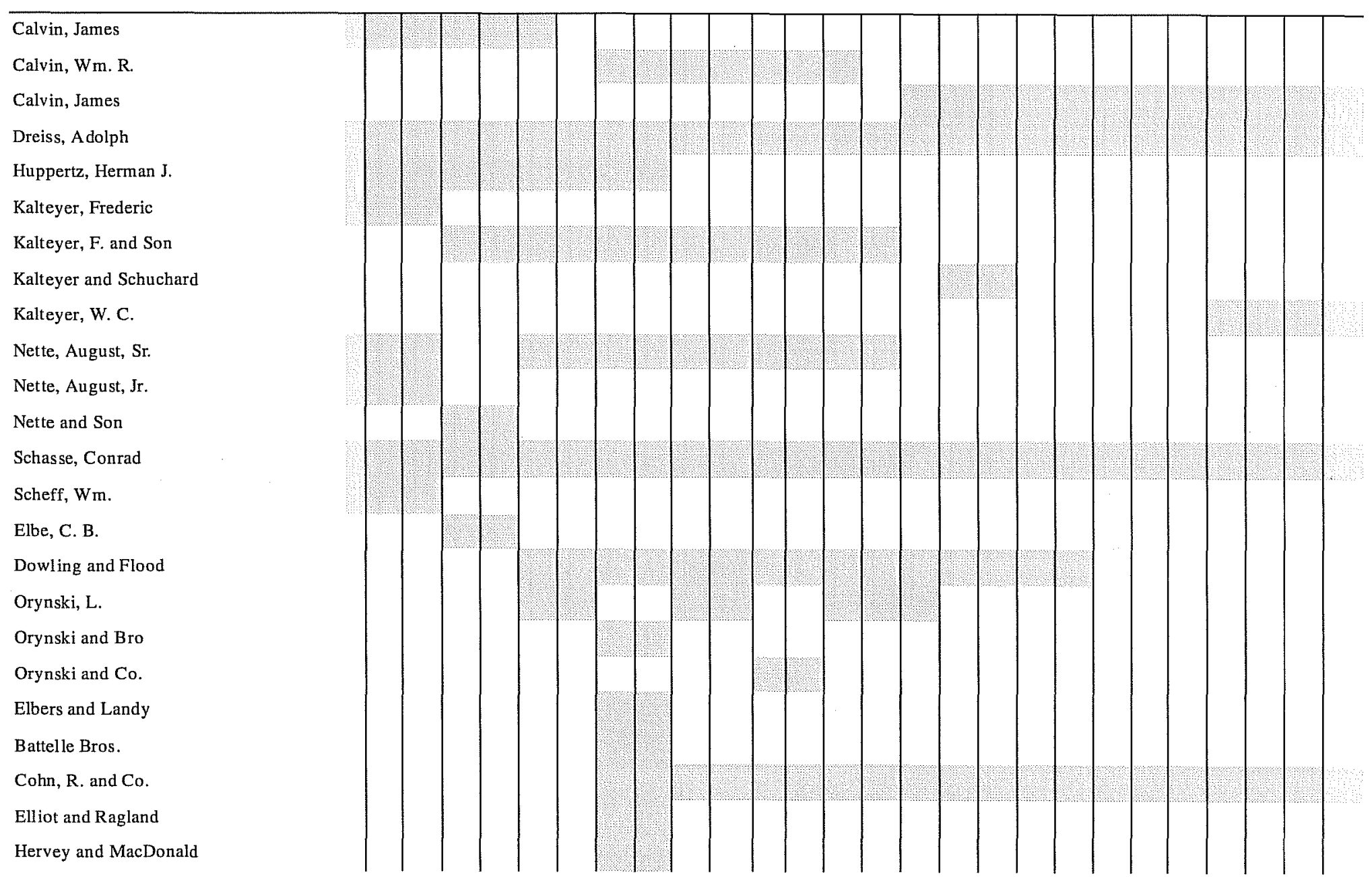


Appendix A. continued

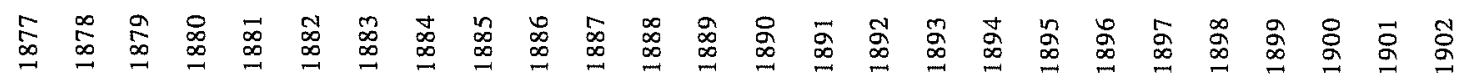

Wetzstein, E. B.

Wetzstein, Mrs. E. B.

Raglan and Co. (City Drug Store)

Raglan and Schachner (City Drug Store)

City Drug Store

Rice Bros.

Blair, Henry, A.

Landry, J. Omar

Bodemann, J. U.

D'Albini, Wm.

D'Albini, Wm. and Co.

Devine, James D.

Jones, Joseph H.

Lockert, R. H.

Wheatley Bros.

Ernest, I. W. (India Drug)

Schuchard, H.

Spellessy, C.

Spellessy, Thomas J.

Voelcker, R. F. (Central)

Yarbrough and Son

Yarbrough and Giles

Aransas Pass Drug Store

Colwell, F. C.

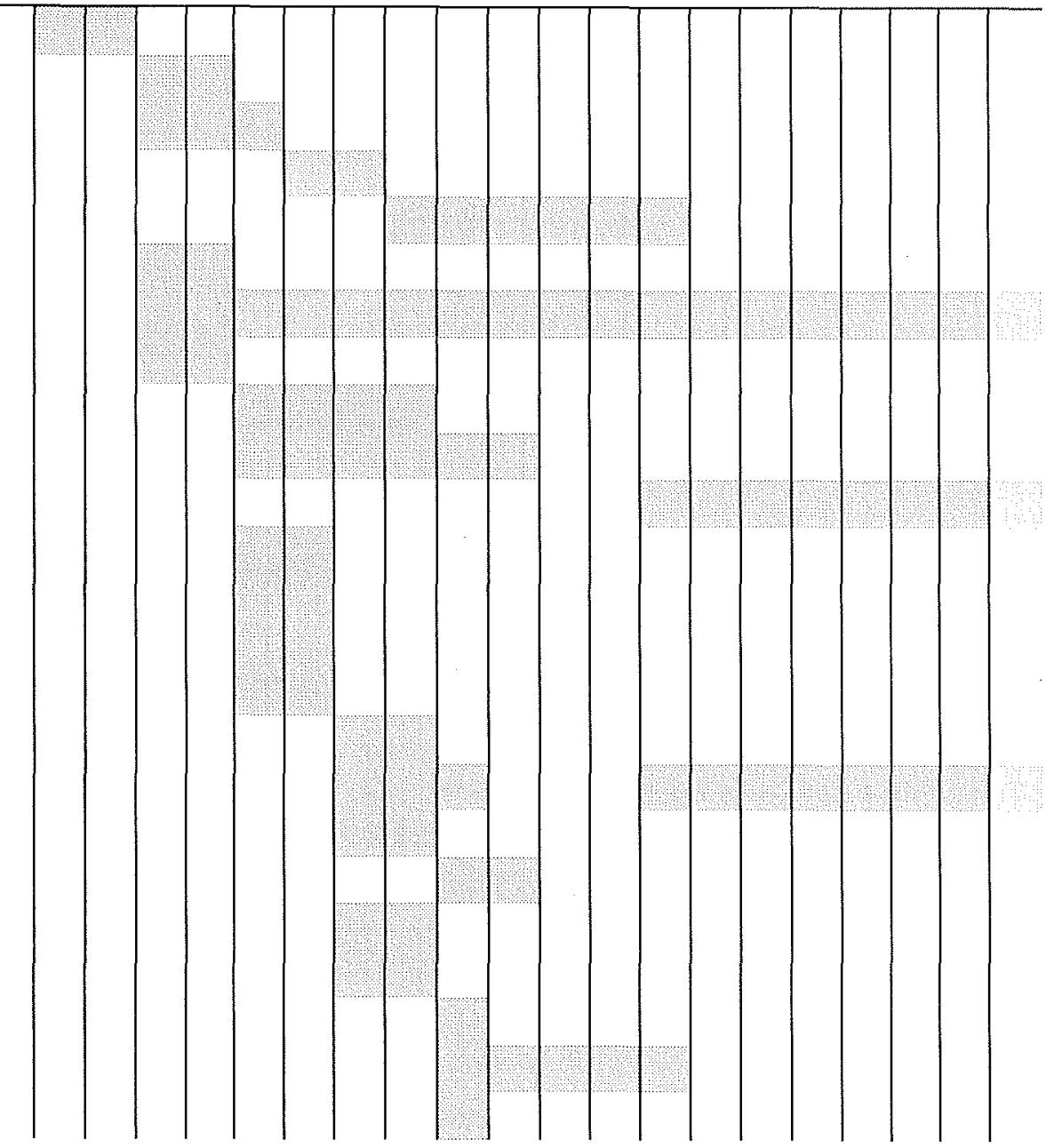


Appendix A. continued

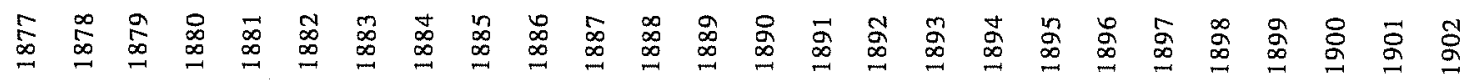

Cunningham's Drug Store

Downey, J. W.

Duncan, T. B.

Farmer Drug Store

Hogue, Elton

Martinez, $\mathrm{H}$.

McLordom and Wilson

Miller, Henry W.

Miller, Mrs. Henry W.

Mission Drug Store

San Pedro Drug Store

San Pedro Pharmacy

Sch weppe, August

Stein, P. S.

Sunset Drug Store

Tip and Silverthorn

Appmann, Wm.

Campbell, Carl

Crescent Pharmacy

Harrison, J. T.

Jungkind, E.

Jungkind and Fischer

Koch, J. G.

Lee, L. R.

(1)


Appendix A. continued

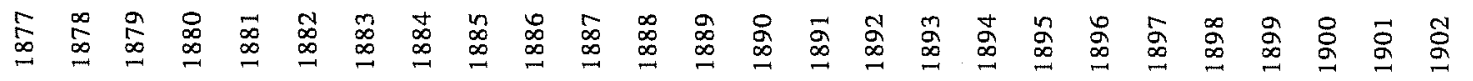

Mei ssners West End

Post Office Drug Store

Reuss, E. W.

San Antonio Drug Co. (wholesale)

Sarro, Joseph

Smith, Mrs. R. B.

Spahn, Louis

Willey, John A.

Booker, E. M.

Bristow, B. W.

Central Drug Store

Duncan, T. B. (Central Drug)

Diaz, F. A. and Co.

James, W. F.

Jones and Virden

Silverthom and Waynel

Silverthom and Wagner

Wlash, J. M.

Young, N. C.

Belcia, C. E.

Petty, J. M.

Pfeiffer, J.

Tallafero, J. W.

Chappa and Dreiss

Eagle Pharmacy

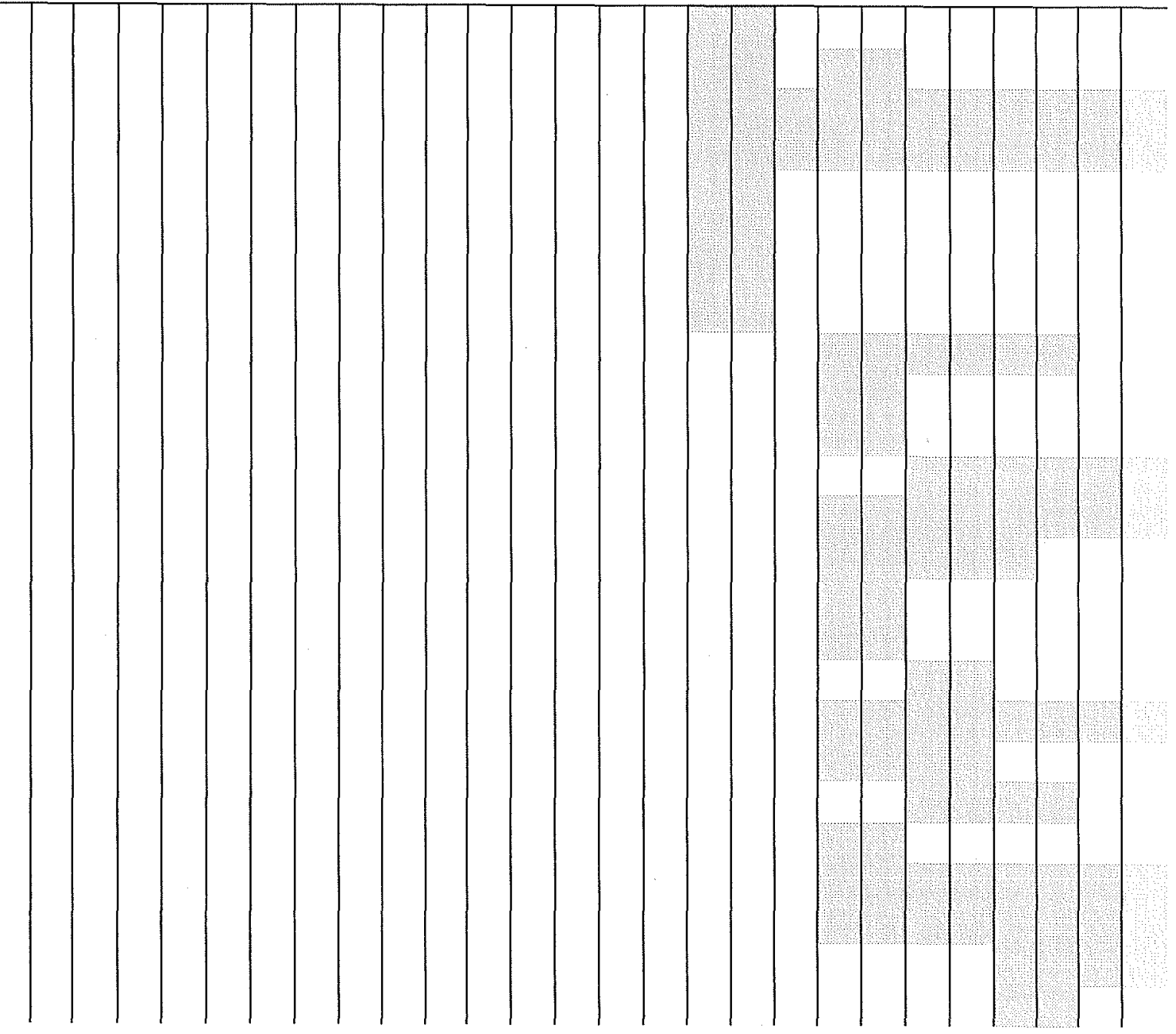


Appendix A. continued

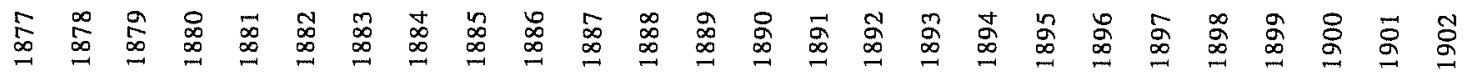

International Drug Store

Milam Square Drug Store

Milburn and Alexander

Milburn Bros.

Miller, Fannie

Patrick Bros.

Burke, J. A.

Canaman, I.

Fischer and Davis

Houck, F. A.

$w_{u}$

Rewand, J. R.

S wearingen Drug Co. 


\title{
Appendix B. Architectural Observations of Subsurface Foundation Feature 6, Henry B. Gonzalez Convention Center Expansion
}

\author{
by Eugene George
}

(1). Mortar was lime-based, showing local manufacture, with a substantial percentage of charcoal from the manufacturing process. The lime has actually been displaced, probably due to moisture transfer. It is interesting to note that the mortar on a reused tile sample (colonial?) used to chink a joint had maintained its lime integrity while the more recent samples had not. This implies that the mortar was poorly prepared. I have foundation samples from San Antonio de Valero (ca. 1744) with mortar still maintaining its integrity.

(2). Quarrying techniques. Stones were rough-quarried to English measurement-dimensions with one principal face worked to a true surface. Stones were removed from quarry by drilling, probably installing a plug and feathers (wedge device) in the hole, then hammering to split the stones from the matrix. The larger stones do not appear to have been salvaged from previous installations, but probably were culls from an active stone yard or cast-offs from other work in progress.

(3). Other than facing a principal surface, stones were installed rough from the quarry. One comer stone showed preparation with sockets for $2 \times 12$ wood joists at twenty-inch centers. This was probably a cast-off from another project.

(4). Artistry was poor, but satisfactory for loads imposed. The foundation walls were haphazardly coursed, using both small and large stones. Vertical and horizontal joints were packed with smaller stones (rejuntado, rejoneado) with a Hispanic technique common to the region. It is interesting to note that the foundation observed revealed no structural failures. Given the techniques employed, these foundations were undoubtedly built by persons of Mexican ethnicity.

(5). As an educated guess on the time of installation, a reasonable date would be between 1865 and 1885 . Stone houses of known dates built on King William Street utilized similar stones, probably from the same quarry and employing similar artisanal techniques. 
Appendix C. List of Artifacts

\begin{tabular}{|c|c|c|c|c|c|c|c|c|c|c|c|c|c|c|c|c|c|c|c|c|c|c|c|c|c|c|c|c|c|c|c|c|c|c|c|c|c|}
\hline \multirow[b]{2}{*}{$\mathrm{Bag}$} & \multirow[b]{2}{*}{ Fe at ure \# } & \multicolumn{12}{|c|}{ Ceramics } & \multicolumn{8}{|c|}{ Glass } & & \multicolumn{4}{|c|}{ Household } & \multicolumn{6}{|c|}{ Personal } & \multicolumn{5}{|c|}{ Construction } \\
\hline & & 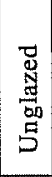 & 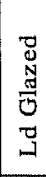 & $\begin{array}{l}3 \\
3 \\
\square \\
\square\end{array}$ & $\begin{array}{l}\vec{\Delta} \\
\vec{z} \\
\text { 茎 }\end{array}$ & 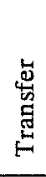 & 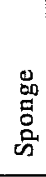 & 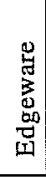 & 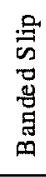 & 胥 & 总 & 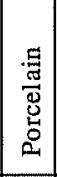 & 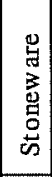 & $\frac{\vec{y}}{U}$ & $\frac{y}{0}$ & 㤩 & 品 & $\frac{g}{\mathscr{g}}$ & 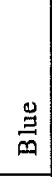 & $\frac{\mathscr{a}}{3}$ & 泀 & 䓂 & 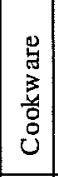 & 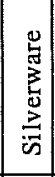 & 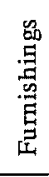 & 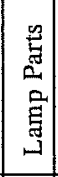 & 号 & $\begin{array}{l}\frac{n}{0} \\
\frac{0}{0} \\
0 \\
0 \\
0\end{array}$ & 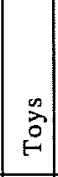 & 䓌 & 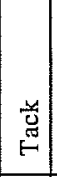 & 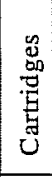 & $\begin{array}{l}\frac{a}{0} \\
3 \\
0 \\
\overrightarrow{0} \\
3 \\
3\end{array}$ & 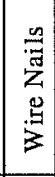 & 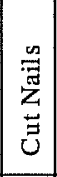 & 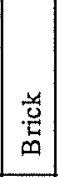 & 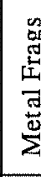 \\
\hline 1 & 1 & & & 1 & & 1 & & & & 1 & & 1 & & 11 & & 1 & 1 & 5 & & & & & & & & 10 & 2 & & 2 & & & & & & & 1 & \\
\hline 2 & 2 & & & 1 & & 1 & & & 1 & & & & & 1 & & & & 1 & & & & & & & & & & & & & & & & & & & \\
\hline 3 & 7 & 2 & & 1 & & 1 & 1 & & 1 & & & & & & & & & & & & & 40 & & & 1 & & & & & & 1 & & & 3 & 1 & & \\
\hline 4 & 11 & & 1 & 24 & & & 1 & & & & & 2 & 3 & 5 & & 2 & & 7 & 1 & 2 & & 6 & & & & & 1 & & & & & & 2 & 1 & & & \\
\hline 5 & 6 & & & & 1 & & & & & & & & & 3 & 5 & 6 & & & 4 & 2 & & & & & & & & & & & & & 3 & & 2 & & 3 \\
\hline 6 & 13 & & & 4 & & 2 & & & & & 3 & & & 4 & & & 1 & & & & 10 & & & & & & 1 & & & & & 1 & & & & & \\
\hline 7 & 14 & & & 2 & & & & & & & & & & 5 & & & 4 & & & & & & & & & & & & & & & & & & & & \\
\hline 8 & $16 \mathrm{a}$ & & & 2 & & & & 1 & & & & & 5 & & & & & & & & & & & & 1 & & & & & & & & & & & & \\
\hline 9 & $16 \mathrm{~b}$ & & & 2 & & 3 & & & & & 1 & & 7 & & & & & & & & & 1 & 3 & 1 & 1 & & & & 3 & & & & & 2 & 2 & & \\
\hline 10 & 18 & & & 1 & & & & & & & & & 1 & 2 & & & & & & & & & & & & & & & & & & & & & & & \\
\hline 11 & 19 & & & 1 & & & & & & 1 & & & & 6 & & & & & & & & 1 & & & & & & & & & & & & & & & 1 \\
\hline \begin{tabular}{|l|}
12 \\
\end{tabular} & 21 & & & 1 & & & & & & 1 & & & & & & & 1 & & & & & & & & & & & & & & & & & & & & \\
\hline 13 & 23 & & & 5 & & & & & & & & & 1 & & & & & 1 & & & & & & & & & & & & & & & & & & & \\
\hline \begin{tabular}{|l|}
14 \\
\end{tabular} & 24 & & & 7 & & 1 & & & 2 & & & & 14 & 2 & & 3 & & 3 & & & & 12 & & & & & & & & 3 & 6 & & & & 4 & & \\
\hline 15 & 25 & & & & & & & & & & & & 5 & & & & & 1 & & & & & & & & & & & 2 & & & & & & & & \\
\hline 16 & 6 (in mortar) & & & & & & & & & & & & & & & & & & & & & 1 & & & & & & 1 & & & & & 4 & & 6 & 2 & 1 \\
\hline & Totals & 2 & 1 & 52 & 1 & 9 & 2 & 1 & 4 & 3 & 4 & 3 & 36 & 39 & 5 & 12 & 7 & 18 & 5 & 4 & 10 & 61 & 3 & 1 & 3 & 10 & 4 & 1 & 7 & 3 & 7 & 1 & 9 & 6 & 15 & 3 & 5 \\
\hline
\end{tabular}


